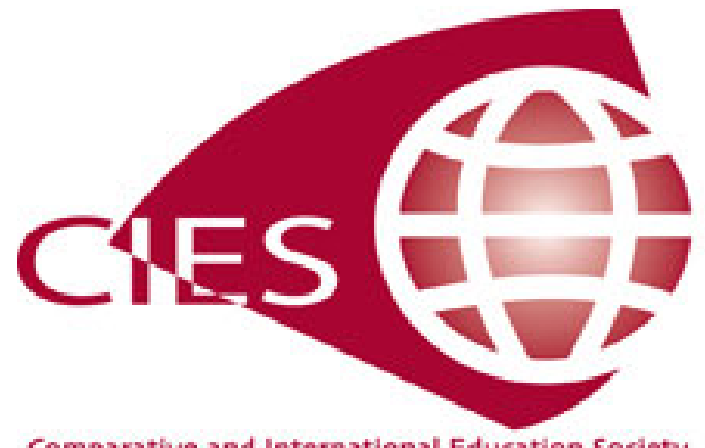

Comparing Civic Competence among European Youth: Composite and Domain-Specific Indicators Using IEA Civic Education Study Data

Author(s): Bryony Louise Hoskins, Carolyn Barber, Daniel Van Nijlen, Ernesto Villalba

Source: Comparative Education Review, Vol. 55, No. 1 (February 2011), pp. 082-110

Published by: The University of Chicago Press on behalf of the Comparative and International Education

Society

Stable URL: http://www.jstor.org/stable/10.1086/656620

Accessed: 24/05/2011 04:33

Your use of the JSTOR archive indicates your acceptance of JSTOR's Terms and Conditions of Use, available at http://www.jstor.org/page/info/about/policies/terms.jsp. JSTOR's Terms and Conditions of Use provides, in part, that unless you have obtained prior permission, you may not download an entire issue of a journal or multiple copies of articles, and you may use content in the JSTOR archive only for your personal, non-commercial use.

Please contact the publisher regarding any further use of this work. Publisher contact information may be obtained at http://www.jstor.org/action/showPublisher?publisherCode=ucpress.

Each copy of any part of a JSTOR transmission must contain the same copyright notice that appears on the screen or printed page of such transmission.

JSTOR is a not-for-profit service that helps scholars, researchers, and students discover, use, and build upon a wide range of content in a trusted digital archive. We use information technology and tools to increase productivity and facilitate new forms of scholarship. For more information about JSTOR, please contact support@jstor.org.

The University of Chicago Press and Comparative and International Education Society are collaborating with JSTOR to digitize, preserve and extend access to Comparative Education Review. 


\title{
Comparing Civic Competence among European Youth: Composite and Domain-Specific Indicators Using IEA Civic Education Study Data
}

\author{
BRYONY LOUISE HOSKINS, CAROLYN BARBER, DANIEL VAN NIJLEN, \\ AND ERNESTO VILLALBA
}

\begin{abstract}
Addressing the European Union monitoring of civic competence, this article presents a composite indicator of civic competence and four domain indicators. The data used are from the 1999 IEA Civic Education study of 14-year-olds in school. The results demonstrate the complexity of the various influences on the development of civic competencies across countries rather than support for a single or unidirectional theoretical explanation. The nation's years of democracy play both a positive and a negative role on different aspects of civic competence, while citizenship education has better than expected consequences in some countries.
\end{abstract}

\section{Introduction}

In the context of renewed interest in comparative research as it informs educational policy (Watson 2001; Maroy 2004; Mok 2005) and the use of internationally collected data to enhance monitoring capacities for policy making, we aim to develop a single composite indicator of civic competence and four domain indicators: citizenship values, social justice values and attitudes, participatory attitudes, and cognitions about democratic institutions. Composite indicators, in this situation, provide researchers and policy makers with insights into general trends on civic competence across a large number of countries. We also describe and account for cross-country differences for both the aggregate scores and for the four domains.

This article builds on efforts to develop a Civic Competence Composite Indicator created for use within the European Union educational policy context. ${ }^{1}$ As part of the Active Citizenship for Democracy project, conducted

1 The 2007 council conclusions on "A Coherent Framework of Indicators and Benchmarks" (Education Council 2007) identified civic competence as one of the 16 indicators to be used to measure progress made on the Lisbon Strategy in the field of education and training. (The Lisbon Strategy is the European Union policy process to increase competitiveness and greater social cohesion in Europe by 2010.) This competence was also established as one of the eight key competencies that young people

Received March 20, 2009; revised November 15, 2009, and May 10, 2010; accepted June 4, 2010; electronically published January 27, 2011

Comparative Education Review, vol. 55, no. 1.

(C) 2011 by the Comparative and International Education Society. All rights reserved.

$0010-4086 / 2011 / 5501-0004 \$ 10.00$ 
in cooperation with the Council of Europe and based at the European Commission Centre for Research on Lifelong Learning, Hermann Joseph Abs and Rudd Veldhuis (2006) created an inventory of the knowledge, skills, values, and attitudes required in Europe to achieve civic competence. ${ }^{2}$ They focus on knowledge of the political and legal system, democracy, the role of media, the function of voluntary associations, history, culture, and current affairs as components of civic competence. In the area of skills, they focus on components of critical reflection, communication, persuasion and building alliances, conflict resolution, and intercultural skills. Finally, the inventory also emphasizes the attitudes of responsibility, self-efficacy, trust, openness to change, and the values of a belief in democracy, the rule of law, equality, social justice, human rights, freedom, fairness, sustainable development, and respect for difference. This process is further documented in appendix A (in the online version of this issue).

Indicators of competencies have typically been developed using data collected by the Organization for Economic Cooperation and Development (OECD) through the Program for International Student Achievement (PISA), which are thought to assess influences on future competitiveness (Sahlberg 2006). In contrast, data collected from studies on civic education conducted by the International Association for the Evaluation of Educational Achievement (IEA) may be more appropriate to consider as a source for a national indicator of civic competence due to its focus on democratic outcomes. The development of the Civic Competence Composite Indicator (CCCI), described in this article, resulted from a discussion as to how IEA data could be used to monitor civic competence in Europe. The resulting indicator that we have developed draws upon data from IEA's 1999 Civic Education Study (CIVED), while keeping in mind that a large number of European countries that participated in the 1999 study are also participating in the 2009 IEA International Citizenship and Civic Education Study (ICCS: IEA 2007).

In this article we first define civic competence by identifying the knowledge, skills, attitudes, and values needed for active citizenship, using research from comparative education (Hahn 1998; Torney-Purta et al. 2001; Kennedy et al. 2007) and comparative political science (Almond and Verba 1963; van Deth et al. 2007) to inform our framework. We then examine the CIVED

across Europe should develop by the end of their initial education and training (Education Council 2006). Civic competence has become a focus of European Union education policy as a means of enhancing democracy and social cohesion in the face of increasing diversity and a persistent "democratic deficit" (Follesdal and Hix 2005, 1).

${ }^{2}$ Active Citizenship in a Learning Context was a 3-year project (2005-8) led by the European Commission Centre for Research on Lifelong Learning. The major outcomes of the project have been the Active Citizenship Composite Indicators (Hoskins 2006; Hoskins and Mascherini 2009), the CCCI (Hoskins et al. 2008), and the Impact of Education on Active Citizenship (Hoskins et al. 2008). For further details of this project, see appendix A (in the online version of this issue), as well as the Web site http://active-citizenship.jrc.ec.europa.eu. 
data set and compare available scales and items to the components of our definition of civic competence to build our domain indicators. After this, we build a model of civic competence, using factor analysis, and construct the composite indicator and the four domain measures.

In a second step we examine average CCCI scores, as well as average scores for each of the CCCI domains, across European countries. We then explore alternative hypotheses that the sociopolitical history of a democratic nation-state influences the levels of civic competence. That is, either the number of years of uninterrupted democracy will be associated with an increase in the levels of civic competence within a society or the number of years of uninterrupted democracy will be associated with youth apathy and not civic competence. In addition, we explore a number of other contributing factors to the levels of youth civic competence: national conceptual understandings of citizenship, economic development, and civic education. We conclude that many different factors influence the levels of civic competence, which can be seen within the complexity of the country groupings within the results. This finding challenges the development of new theory.

\section{Conceptualizing Civic Competence and Why It Might Vary Cross-Nationally}

Although a contested concept (Hyland 1994), we refer to a "competence" as a complex combination of knowledge, skills, values, and attitudes that lead to effective, embodied human action in the world (Hoskins and Crick 2008). Similarly, Rychen and Salganik (2003) define "competence" to include both cognitive and noncognitive dimensions. More specifically, we define "civic competence" as a combination of knowledge, skills, attitudes, and values that enables a person to become an active citizen. In the European Union, active citizenship is further defined as "participation in civil society, community and/or political life, characterized by mutual respect and non-violence and in accordance with human rights and democracy" (Hoskins 2006). Almond and Verba (1963) have used the concept of "civic competence" in a similar way to describe the attitudes of self-efficacy and citizenship norms that individuals require to become a competent and effective active citizen, while Putnam (1993) uses the notion of citizens virtues within a civic community to refer similarly to civic competence, identifying the following qualities: active participation in public affairs, equality among citizens, solidarity, tolerance, and the ability to collaborate with others. ${ }^{3}$

There are reasons to expect that civic competence levels may vary from

${ }^{3}$ The difference with Putnam's approach is that in addition he identifies "self interest that is alive to the interests of others" (Putnam 1993, 88) as an aspect of civic competence, while solidarity is more pronounced in our definition of civic competence. Furthermore, although Putnam uses the notion of trust, we do not because of the ambiguity surrounding the issue of trust of political leaders. Recent research has shown that trust is associated more with the current political climate than with individual competences to democratically participate (Mascherini et al. [2007] in Europe; Torney-Purta et al. [2004] in Bulgaria, Chile, and Colombia). 
nation to nation. Here we discuss three factors that may account for such variation: political history, economic development, and education systems.

\section{Political History}

An important factor that may influence the development of civic competence is a country's civic culture (Almond and Verba 1963). Civic cultures are the countries' norms toward citizenship in terms of the prevailing attitudes and values toward the political system and each individual's role within the system, including a cognitive element. These norms derive from the sociopolitical history, introduction of democracy, and development of the nation-state. The cornerstone to the process of developing democratic civic norms is the duration of stable democracy and therefore the possibility of a civic culture being socialized from one generation to the next. For example, Gabriel Almond and Sydney Verba (1963) noted a high degree of political alienation among adults in Italy, resulting from their experience of fascism, the Second World War, and relatively recent formation of the nation-state. Further research has confirmed that the number of years of uninterrupted democracy has had a consistent and stable association with higher levels of democratic participation (van Deth et al. 2007) and greater levels of liberal values such as tolerance (Weil 1985).

If this proposition is correct, we would expect to see the following country groupings for the Civic Competence Composite Indicator and on all four domain indicators: (1) Eastern European countries (including the eastern part of Germany), which have experienced communist regimes and have had a very recent transition to liberal democracy, would have the lowest levels of civic competence; (2) countries (e.g., Greece, Cyprus, ${ }^{4}$ and Portugal) that experienced breaks in democracy and have either undergone fascism, dictatorship, and/or occupation and then only recently (within the past 65 years) have undergone transition back to democracy, as well as countries (e.g., Italy and West Germany) that have experienced fascism and transitions to democracy after the Second World War; (3) countries that have had a stable and continuous experience of democracy over the past 65 years or more (e.g., Sweden, Norway, Denmark, Finland, Belgium, Switzerland, and England).

The alternative hypothesis, however, is that in countries with longer and more stable democracies and where there is a higher (in comparison to other countries in Europe) level of participation in their adult populations, such as Sweden, Denmark, Norway, and England (Hoskins et al. 2006; van Dethet al. 2007; Hoskins and Mascherini 2009), young people have become much more apathetic. Thus, young people from countries that have experienced recent transition to democracies and less stability could value democracy more highly and have a greater intention to participate because of

\footnotetext{
${ }^{4}$ In this study, this involves only the Greek-speaking section of Cyprus.
} 
the fragility of the democratic institutions. In this case it would be the instability of political external factors and recent memories of lack of democracy that generate the values associated with civic competences within the youth age group (see Torney-Purta et al. 2008). For this proposition to be correct, we would expect to see the reverse country groupings, in particular for the domains of civic values and attitudes toward participation, with former communist countries at the top; followed by Germany (which includes West Germany) and the Southern European countries of (Greek-speaking) Cyprus, Greece, and Italy; and, finally, the long-standing stable democracies of Sweden, Norway, Denmark, Finland, Belgium, Switzerland, and England.

Within the political history of countries within Europe, another distinguishing factor could influence the levels of civic competence and how citizenship of a country is conceptualized. For instance, Hans Kohn (2008) describes two forms of citizenship: civic and ethnocultural notions of national citizenship. The ethnic notions of citizenship of a country are defined by descent, a common language, and ethnic culture. This has been historically adopted by predominantly former communist countries, while Germany as a whole has been historically associated with an ethnic conceptualization of citizenship (Brubaker 1996). The civic notion of citizenship is defined through political citizenship, which includes equal political rights and democratic institutions (Shulman 2002). This definition of citizenship has been associated with Western European countries, such as England and France, and the Nordic countries (Sweden, Denmark, and Finland). If the conceptualization of citizenship had a significant influence on the results, we would expect countries with a civic and political conceptualization of citizenship to have higher levels of civic competence, in particular regarding civic attitudes, social justice, and tolerance.

\section{Economic Development}

Another factor seen to influence citizenship values and behavior is economic development. For instance, Ronald Inglehart and Christian Welzel (2005) posit that people who have had a secure and affluent childhood will tend to develop self-expression values (i.e., values emphasizing self-fulfillment, freedom, autonomy, gender equality, tolerance), which overlap with the above-defined conception of civic competence associated with democracies. By contrast, people who have grown up under conditions of scarcity and insecurity will tend to develop survival values (i.e., values stressing economic and physical security), which underpin citizen identities, particularly in authoritarian states (Inglehart and Welzel 2005).

If economic prosperity is particularly influential, then the results for the Civic Competence Composite Indicator and, in particular, the Social Justice domain would resemble those associated with the positive influence of the numbers of years of stable democracy increasing the levels of civic compe- 
tences. However, there are a small number of exceptions in the expected country groupings, with the most notable being Germany, which is economically highly developed but has only recently transitioned to democracy in the East and only relatively recently transitioned from fascism to liberal democracy in the West. The other exception is Greek-speaking Cyprus, which is economically more prosperous than other countries that have experienced recent or interrupted democracy.

\section{Education}

In addition to political history, conceptualization of national citizenship, and economic development, civic education may influence the results in two different ways. First, civic education as a discrete curricular topic may raise cognitive and attitudinal scores. Second, the methods used to teach civic education (e.g., through an open classroom climate) may raise cognitive and attitudinal scores.

Richard Niemi and Jane Junn (1998) show that civic courses in the United States can help develop civic knowledge and skills, a finding supported by evaluation research on citizenship education programs in Poland (Slomczynski and Shabad 1998), in Bosnia (Soule 2003), and in postapartheid South Africa (Finkel and Ernst 2005). Education, however, has been found to socialize individuals toward the prevailing norms of a country's regime with some time lag (Weil 1985). This is particularly important in Europe because even though most countries had citizenship education in their curricula, civic education during the period of this research was under dramatic change in Eastern European countries. For instance, Elisabeth Buk-Berge $(2006,534)$ highlights that civic education in these countries was "previously based on ... indoctrinating [students] into builders of communism, ... it had to be transformed to provide the education of citizens living in a democracy." Thus, we would expect civic competences to be lower for Eastern European countries, even if civic education is included in their curricula.

If civic education alone as a discrete subject in secondary education has a strong, positive influence on civic competence and, in particular, the cognitive dimension of civic competence, we expect countries that did not have civic education as a discrete subject (England, Belgium [French-speaking (Fr) ], Denmark, Finland, and Hungary) to have lower scores. Combining the expected results for the benefits of civic education together with a history of democratic education, we expect that Sweden and Norway would have the highest scores; followed by Italy, West Germany, Greece, Cyprus, and Portugal; and then the former communist countries of Estonia, Poland, Slovenia, Czech Republic, Latvia, Lithuania, Slovakia Romania, Bulgaria, and East Germany. Although the CIVED study took place after the reunification of Germany, expectations are difficult to make for the country as a whole. 
In addition to content, teaching methods may be crucial. The CIVED report and subsequent secondary analysis (Torney-Purta et al. 2001; TorneyPurta et al. 2008) highlighted that learning within the school context, especially when classrooms are open for discussion, can influence civic knowledge, skills, and attitudes. Similarly, Carol Hahn (1998) reported that open climate for learning, group work, opportunities to participate in decision making, and discussing controversial issues enhanced positive civic attitudes. Furthermore, she noted that Danish schools tended to exhibit such classroom interaction patterns more so than was the case in the Netherlands and England. Torney-Purta and colleagues also found that the transition countries from Eastern Europe tended to have less open classroom climates than their Western European counterparts (Torney-Purta et al. 2001; Torney-Purta 2002). If open classroom climate is influential on the results, we would expect the Nordic countries of Sweden, Denmark, Finland, and Norway, which traditionally have had open class climates, to have higher civic competence scores.

In total, the factors described above all have varying degrees of influence on the development of civic competence for the countries concerned. This interaction of factors is what makes the assessment of country distinctions more complex.

\section{Measuring Civic Competence Using the IEA Civic Education Study}

\section{Data Source}

In order to form a composite indicator of civic competence as conceptualized by members of the Active Citizenship for Democracy project, we relied on data from the CIVED survey (sample of 14-year-olds). This is the only existing international data source collected from nationally representative samples that tests knowledge, skills and values, attitudes, and intended behavior relating to civic competence. The 1999 CIVED survey was administered in 28 countries by IEA, an international consortium of educational research institutes that conducts large-scale research studies on many aspects of education. The aim of the 1999 CIVED study was to "understand how young people are prepared to undertake their role as citizens" (Torney-Purta et al. 2001), with a special interest in the experiences of youth in recently established democracies. It tested students at schools in the normative grade for 14-year-olds within each country (with an average age of respondents being above 13.5 years old).

CIVED's framework broadly defines civic education to include the following content domains: (1) democracy/citizenship, (2) national identity/ international relations, and (3) social cohesion and identity. "Democracy/ citizenship" refers to the meaning of democracy and the role and practices of its institutions and of citizens. "National identity/international relations" refers to national identity and loyalty and the implications of this for inter- 
national relations. "Social cohesion and identity" refers to young people's attitudes toward groups experiencing discrimination.

\section{Participants and Procedures}

Altogether, approximately 90,000 students participated in the CIVED 14year-olds study, of which 72,129 were within the geographical region of Europe. As described by Heiko Sibberns and Pierre Foy (2004), participants were selected using a two-stage sampling process, in which, first, schools were selected, and second, a single, intact civic-related or untracked homeroom class of students from the target grade was selected. In many countries, the sampling of schools was stratified according to key school and community characteristics (e.g., urbanicity). Weights made available as part of the CIVED data set allow researchers to take into account this sampling design in order to make unbiased, nationally representative estimates of students' civic knowledge, behaviors, and attitudes (see Schulz and Sibberns 2004).

Once participants were selected, individuals were tested on their knowledge of civic-related content, skills in interpretation of civic-related material, concepts, attitudes, and actions. Knowledge and skills items were coded as correct or incorrect responses in the "civic knowledge test," while concepts, attitudes, and actions were administered using a four-point scale (e.g., not important, somewhat unimportant, somewhat important, and very important). Other survey items included questions that referred to either the student's confidence in classroom participation or the classroom climate, while teacher and administrator questionnaires provided additional information about the school context of citizenship education.

\section{Scaling of CIVED Data}

As part of IEA's preliminary analysis of CIVED data, researchers sought to identify measures of civic knowledge, attitudes, values, and expected political participation that could be created from the items administered. As described by Schulz and Sibberns (2004), the first part of this process involved conducting a series of confirmatory factor analyses (CFAs) to test the hypothesized dimensionality of the items presented in the student survey. Altogether, 10 CFA models were run to test the dimensionality of the following constructs: civic knowledge, norms of citizenship, attitudes toward government responsibilities, trust, national identity, attitudes toward opportunity, attitudes toward immigrant rights, school participation, expected participation, and classroom climate. ${ }^{5}$ From these models, a total of two knowledge dimensions and 18 attitudinal or value dimensions were identified.

After identifying these dimensions, researchers in the CIVED study created scales to capture each dimension using item response theory (IRT)

\footnotetext{
${ }^{5}$ Not all of the scales have been used in the civic competence composite indicator, and those that have been used will be detailed below.
} 
techniques (Schulz and Sibberns 2004). ${ }^{6}$ CIVED researchers created a total of 14 IRT scales: one for each of the two knowledge dimensions, one for 11 of the 18 attitudinal/value dimensions, and an additional IRT scale combining the two knowledge dimensions into a "total civic knowledge" scale.

Since the initial CFA modeling of data by CIVED researchers, secondary analyses have identified additional scales using the same CFA and IRT techniques. For example, Vera Husfeldt et al. (2005) respecified the model of expected participation to include more dimensions. Among the resulting IRT scales are measures of expectations of informed voting, community participation, and protest activities, as well as a scale of internal political efficacy. Finally, for the purposes of the current analysis, we conducted IRT scaling of one of the dimensions of school participation originally identified by CIVED researchers but not scaled, and we created a new IRT scale measuring students' conceptions of democracy. ${ }^{7}$

\section{Comparing CIVED Measures to the Concept of Civic Competence}

There are differences between the European inventory of indicators on civic competence and the variables developed in the CIVED study (see table 1). First, the CIVED framework focuses on measuring the levels of civic knowledge and skills and identifying the aspects of formal education that enhance students' cognitive performances (Torney-Purta et al. 2001). In contrast, the European civic competence framework aimed to monitor the learning outcomes of civic competence, reflecting the normative position of European policy on the qualities needed for active citizenship in Europe. The European framework is also different because it focuses equally on the affective and cognitive dimensions of learning outcomes, reflecting a focus on measuring competences as opposed to knowledge and skills.

There were further differences between the models due to the scope of the different projects. Aspects of education (e.g., classroom climate) that may influence the development of civic competence are input variables and not individual students' learning outcomes and, as such, were considered beyond the scope of a civic competence indicator and were not considered in the research presented here. In addition, CIVED measured attitudes and values beyond those that were considered as necessary for civic competence, such as attitudes toward economic-related and society-related government responsibilities. In addition, feelings of patriotism and national identity that were covered within the CIVED were not considered to be a part of civic com-

\footnotetext{
${ }^{6}$ In short, IRT techniques allow categorical items (such as Likert scales or knowledge items with right and wrong answers) to be used to measure a continuous variable, such as knowledge or an attitude (Masters and Wright 1997). From a practical perspective, IRT allowed for $(a)$ more precise estimation of scale scores from respondents with missing data on one or more items in the scale and $(b)$ items not fitting the model in a single country to be removed without compromising the international comparability of the measure.

${ }^{7}$ Our Conception of Democracy scale was formed using exploratory factor analytic techniques rather than CFA techniques.
} 
TABLE 1

Content Analysis of Cived Data Set versus Dimension Civic Competence

\begin{tabular}{|c|c|c|}
\hline \multicolumn{2}{|l|}{$\begin{array}{l}\text { Dimensions of Civic Competence (Hoskins } \\
\text { et al. 2008) }\end{array}$} & \multirow{2}{*}{$\begin{array}{l}\text { Source in IEA CIVED } 1999 \text { Covering the } \\
\text { Dimension } \\
\text { KNOWL-knowledge of content }{ }^{\mathrm{a}}\end{array}$} \\
\hline Knowledge: & & \\
\hline $\begin{array}{l}\text { Key elements of the political and legal } \\
\text { system (human rights, social rights and } \\
\text { duties, parliamentary government, the } \\
\text { importance of voting; local, national, } \\
\text { European, international levels) }\end{array}$ & ++ & $\begin{array}{l}\text { IC: citizenship rights and duties } \\
\text { IB: institutions and practices in democracy } \\
\text { IA: democracy and its defining characteris- } \\
\text { tics } \\
\text { IIB: international relations }\end{array}$ \\
\hline $\begin{array}{l}\text { Basic institutions of democracy, political } \\
\text { parties, election programs, and the } \\
\text { proceedings of elections }\end{array}$ & ++ & $\begin{array}{l}\text { IB: institutions and practices in democracy } \\
\text { IA: democracy and its defining characteris- } \\
\text { tics }\end{array}$ \\
\hline $\begin{array}{l}\text { The role of the media in personal and } \\
\text { social life }\end{array}$ & + & $\begin{array}{l}\text { IC: citizenship rights and duties (items } 4 \\
\text { and 18) }\end{array}$ \\
\hline $\begin{array}{l}\text { Social relationships between groups in so- } \\
\text { ciety (e.g., social class) }\end{array}$ & + & $\begin{array}{l}\text { IC: citizenship rights and duties } \\
\text { IIIA: social cohesion and diversity }\end{array}$ \\
\hline $\begin{array}{l}\text { History and cultural heritage of own } \\
\text { country; predominance of certain } \\
\text { norms and values }\end{array}$ & - & \\
\hline $\begin{array}{l}\text { Different cultures that exist in the local, } \\
\text { regional, and national context }\end{array}$ & - & \\
\hline $\begin{array}{l}\text { Main events, trends, and change agents } \\
\text { of national, European, and world his- } \\
\text { tory }\end{array}$ & - & \\
\hline $\begin{array}{l}\text { The function and work of voluntary } \\
\text { groups }\end{array}$ & + & $\begin{array}{l}\text { IC: citizenship rights and duties (items } 7 \\
\text { and } 34 \text { ) }\end{array}$ \\
\hline Knowledge of current political issues & - & \\
\hline Skills: & & $\begin{array}{l}\text { SKILS-skills in interpretation of material } \\
\text { with civic or political content } \mathrm{a}^{\mathrm{a}}\end{array}$ \\
\hline $\begin{array}{l}\text { To be able to evaluate a position or deci- } \\
\text { sion, take a position, and defend a po- } \\
\text { sition }\end{array}$ & + & $\begin{array}{l}\text { IB: institutions and practices in democracy } \\
\text { (items } 23,24,25,33 \text { [only covering "eval- } \\
\text { uate positions"]) }\end{array}$ \\
\hline $\begin{array}{l}\text { To distinguish a statement of fact from } \\
\text { an opinion }\end{array}$ & + & Items $31,32,37,38$ \\
\hline To resolve conflicts in a peaceful way & - & \\
\hline $\begin{array}{l}\text { To interpret media messages (interests } \\
\text { and value systems that are involved, } \\
\text { etc.; critical analysis of the media) }\end{array}$ & + & $\begin{array}{l}\text { IC: citizenship rights and duties (items } 4 \text {, } \\
\quad 14,18,23,24,25,33,34,36)\end{array}$ \\
\hline $\begin{array}{l}\text { To be capable to critically examine infor- } \\
\text { mation }\end{array}$ & + & $\begin{array}{l}\text { IB: institutions and practices in democracy } \\
\quad(\text { items } 30,31,33)\end{array}$ \\
\hline $\begin{array}{l}\text { To possess communication skills (to be } \\
\text { able to present in verbal and/or writ- } \\
\text { ten manner your ideas) }\end{array}$ & - & \\
\hline $\begin{array}{l}\text { To be able to monitor and influence pol- } \\
\text { icies and decisions, including through } \\
\text { voting }\end{array}$ & - & \\
\hline $\begin{array}{l}\text { To use the media in an active way (not as } \\
\text { consumer but as a producer of media } \\
\text { content) }\end{array}$ & - & \\
\hline To build coalitions and to cooperate & - & \\
\hline $\begin{array}{l}\text { To be able to live and work in a multicul- } \\
\text { tural environment }\end{array}$ & + & IIIA: social cohesion and diversity \\
\hline \multicolumn{3}{|l|}{ Attitudes: } \\
\hline $\begin{array}{l}\text { To feel responsible for your decisions } \\
\text { and actions, in particular, in relation- } \\
\text { ship to other citizens }\end{array}$ & + & $\begin{array}{l}\text { CONFS-confidence in the value of partici- } \\
\text { pation at school }\end{array}$ \\
\hline To feel confident to engage politically & + & $\begin{array}{l}\text { EFFIC_internal political efficacy }{ }^{\mathrm{a}, \mathrm{b}, \mathrm{c}} \\
\text { SCON-self-confidence in one's own partic- } \\
\text { ipation (local context) } \\
\text { partly CONFS }^{\mathrm{a}, \mathrm{b}, \mathrm{d}}\end{array}$ \\
\hline
\end{tabular}


TABLE 1 (Continued)

\begin{tabular}{|c|c|c|}
\hline $\begin{array}{l}\text { Dimensions of Civic Competence (Hoskins } \\
\text { et al. 2008) }\end{array}$ & & $\begin{array}{c}\text { Source in IEA CIVED } 1999 \text { Covering the } \\
\text { Dimension }\end{array}$ \\
\hline $\begin{array}{l}\text { To trust in and have loyalty toward demo- } \\
\text { cratic principles and institutions }\end{array}$ & + & $\begin{array}{l}\text { TRUST-trust in government institutions } \\
\text { (some aspects of political trust) } \\
\text { DEMOC-normative views of democracy } \\
\quad(\text { some items) })^{\text {a,d }}\end{array}$ \\
\hline $\begin{array}{l}\text { To be open to difference, change of own } \\
\text { opinion, and compromise }\end{array}$ & + & $\begin{array}{l}\text { WOMRT - attitude toward women's eco- } \\
\text { nomic and political rights } \\
\text { MINOR-attitudes toward opportunities for } \\
\text { minorities (partially covering openness to } \\
\text { difference) } \text { a,b,c }^{\mathrm{a}}\end{array}$ \\
\hline Values: & & \\
\hline Acceptance of the rule of law & + & $\begin{array}{l}\text { Item in section B on "good citizen": B, } \\
\text { item A21 on democracy }\end{array}$ \\
\hline $\begin{array}{l}\text { A belief in social justice and the equality } \\
\text { and equal treatment of citizens }\end{array}$ & + & $\begin{array}{l}\text { Items in section A on "democracy": A8, A9, } \\
\text { A19, A22 }\end{array}$ \\
\hline $\begin{array}{l}\text { Respect for differences including gender } \\
\text { and religious differences }\end{array}$ & + & Items in section A on "democracy": A9, A19 \\
\hline & & $\begin{array}{l}\text { CTSOC-norms of social-movement } \\
\text { citizenship } \\
\text { WOMRT }^{\mathrm{a}}\end{array}$ \\
\hline $\begin{array}{l}\text { Reject prejudice, racism, and discrimina- } \\
\text { tion }\end{array}$ & + & $\begin{array}{l}\text { Items in section A on "democracy": A8, A22 } \\
\text { MINOR }{ }^{\text {a,b,c }} \\
\text { IMMIG-attitudes toward immigrants' } \\
\text { rights }\end{array}$ \\
\hline $\begin{array}{l}\text { Respect for human rights (equality, dig- } \\
\text { nity, and freedom) }\end{array}$ & + & $\begin{array}{l}\text { CTSOC (item B11) } \\
\text { DEMOC,d }^{\mathrm{a}} \\
\text { WOMRT }^{\mathrm{a}} \\
\text { MINOR }^{\mathrm{a}, \mathrm{b}, \mathrm{c}} \\
\text { IMMIG }\end{array}$ \\
\hline Tolerance toward difference & + & $\begin{array}{l}\text { MINOR }^{\mathrm{a}, \mathrm{b}, \mathrm{c}} \\
\text { WOMRT }^{\mathrm{a}}\end{array}$ \\
\hline A belief in the importance of democracy & ++ & $\begin{array}{l}\text { DEMOC }^{\mathrm{a}, \mathrm{d}} \\
\text { ADGR-attitude toward political rights } \\
\text { for antidemocratic groups } \\
\text { CTCON }^{\mathrm{b}, \mathrm{c}} \\
\text { CTSOC-norms of social-movement } \\
\text { citizenship }\end{array}$ \\
\hline $\begin{array}{l}\text { A belief in the need to preserve the envi- } \\
\text { ronment } \\
\text { Intended behavior: }\end{array}$ & + & $\begin{array}{l}\text { Item in section B on "good citizen": B13 } \\
\text { Item in section C on "government": C10 }\end{array}$ \\
\hline $\begin{array}{l}\text { The intention to participate in the politi- } \\
\text { cal community }\end{array}$ & + & $\begin{array}{l}\text { POLAT_-political activities }{ }^{\mathrm{a}} \\
\text { CTSOC }^{\mathrm{a}} \\
\text { CTCON }^{\mathrm{a}} \\
\text { VOTE-expectations of voting } \\
\text { VO,c }\end{array}$ \\
\hline $\begin{array}{l}\text { The intention to be active in the commu- } \\
\text { nity }\end{array}$ & + & $\begin{array}{l}\mathrm{SCON}^{\mathrm{a}, \mathrm{b}, \mathrm{d}} \\
\text { COMM-expectations of community } \\
\text { participation }^{\mathrm{a}, \mathrm{c}}\end{array}$ \\
\hline $\begin{array}{l}\text { The intention to participate in civil soci- } \\
\text { ety }\end{array}$ & + & 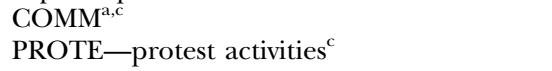 \\
\hline
\end{tabular}

Note. $-++=$ satisfactorily covered, $+=$ partially covered/poorly covered, $-=$ not covered. Items and sections listed come from the CIVED test and survey of 14-year-olds as described in Schulz and Sibberns 2004.

a Scale used in our model and analysis.

b Scales identified but not developed by IEA.

c Scales identified and developed by CEDARS.

d Scale identified and developed by Hoskins et al. 
petence. Third, CIVED assessed students' attitudes in some areas (e.g., attitudes toward citizens' rights for all migrants and actions that were deemed against the law, such as blocking traffic) that were not included in our final list, due to a lack of consensus within Europe as to whether they were reflective of civic competence.

If there was no satisfactory congruence between the dimensions of civic competence and the CIVED-created scales, we explored whether there was some correspondence with specific items measured in the survey. The result of the content analysis showed that most dimensions of civic competence are covered or partially covered (see table 1 ). Aspects related to civic knowledge of one's own country (e.g., national history and cultural heritage) are not covered in the international CIVED study. However, knowledge of basic institutions of democracy and key elements of the political and legal system are relatively well covered.

The knowledge and skills domains are mainly covered by different aspects of the scales directed to assess "knowledge of the content" (KNOWL) and "skills in interpretation" (SKILS). The skills dimension focuses to a large extent on interpreting information, like that usually found in the media, and also covers distinguishing fact from opinion, which is in the European framework. The affective dimensions are covered by the scales on concepts, attitudes, and actions of the student questionnaire.

The dimension of skills has the narrowest coverage. Skills that require interaction, for example, civic skills, such as "to build coalitions, to cooperate" or "to resolve conflict peacefully," cannot be covered within international surveys because it would require observations to test these skills. The loss of these elements from the civic competence composite indicator is quite significant because of their clear importance to becoming an active citizen. The skills that refer to "to be able to live and work in a multicultural environment" also require other types of methodology and questions than those used in CIVED and highlight further the limitations of what can be measured in paper and pencil surveys.

In the case of attitudes, values, and intended behavior, we found 12 scales to be relevant to the dimensions of civic competence. These scales are importance of conventional citizenship (CTCON), importance of social movement-related citizenship (CTSOC), democratic rights (DEMR), attitudes toward women's political and economic rights (WOMRT), attitudes toward opportunities for minorities (MINOR), confidence in participation at school (CONFS), self-confident participation (SCON), internal political efficacy (EFFIC), expectations of community participation (COMM), political activities (POLAT), self-confident participation (SCON), and expectations associated with voting (VOTE). These scales partially cover many of the values, attitudes, and intended behavior dimensions in civic competence, though some dimensions are covered by several scales. For example, "respect for 
human rights" is covered by DEMR, WOMRT, and MINOR. Other dimensions are poorly covered; for example, only one unscaled item seems to cover the dimension "acceptance of the rule of law." Also, although we found some items to cover "strive for justice and equality and equal treatment of citizens," we found no scale that would capture it entirely.

\section{Creating the Civic Competence Indicator}

Developing a Measurement Model

After identifying the 13 individual CIVED IRT scales (11 scales on attitudes, values, and intended behavior, and 2 scales on knowledge and skills) most closely associated with dimensions of civic competence, we sought to create a measurement model to identify a few broad dimensions of civic competence captured by these scales. To accomplish this, we conducted an exploratory factor analysis of 13 IRT scales (see appendix B [in the online version of this issue]). The measurement model, emerging from the factor analysis and the interpretation of the results, has four components: Citizenship Values, Social Justice Values and Attitudes, Participatory Attitudes, and Cognition about Democratic Institutions. Citizenship Values, Social Justice Values and Attitudes, and Participatory Attitudes are mainly related to the affective side of civic competence, while Cognition about Democratic Institutions is mainly related to the cognitive domain. The reliabilities (internal consistencies among the IRT scales) for these four components were satisfactory, varying from 0.645 to 0.786 (see app. B).

\section{Creating a Composite Indicator}

To create the composite indicator of interest, civic competence, we followed the methodological guidelines of Nardo and colleagues (2005). Our composite indicator combined the 13 scales (11 scales on attitudes, values, and intended behavior, and 2 scales on knowledge and skills) mentioned above. The knowledge scales were set to a different international mean and standard deviation than were the attitudinal and value scales. Furthermore, because some of the scales had different units of measurement (Schulz and Sibberns 2004), we carried out an additional standardization procedure in order to combine the scales in a composite measure. The basic standardization technique we applied is the min-max approach, in which all the scales were rescaled so that the standardized values were between zero and one.

Once the data were standardized, we aggregated the various measures by computing the linear weighted sum of the normalized domains or scales. We combined the different weighted scales to create the different nodes of the structure, using an equal weighting scheme with a simple additive method. In other words, each scale was counted equally when calculating a score for the dimensions of civic competency, and each dimension was subsequently counted equally when creating the composite indicator. This needs to be 
kept in mind when examining the results, since a very low performance on the cognitive tests, for example, can be compensated for by very high scores on the other dimensions of values and attitudes.

Ranking Countries according to the Composite Indicator

To obtain country rankings discussed in the next section of the article, we aggregated the individual scores using the sample weights as indicated by Wolfram Schulz and Heiko Sibberns (2004). We then conducted a robustness analysis to examine how variations in rankings derive from different sources of variation in the assumptions. The robustness analysis, which was undertaken with respect to two sources of uncertainty (the structure and the standardization technique), showed no major differences in the rankings presented here and for other approaches (see Hoskins et al. 2008).

\section{Comparing European Countries on the CCCI and Four Domains}

Tables 2-6 present the rankings for the CCCI as well as for the different domains (Citizenship Values, Social Justice Values and Attitudes, Participatory Attitudes, and Cognitions about Democratic Institutions). All of the results (means and standard deviations) are presented using the scale that resulted from the min-max standardization multiplied by 1,000. In addition, we provide the pairwise comparison between mean scores per country at the 5 percent confidence level, with the columns denoting the comparison country.

With respect to CCCI, (Greek-speaking) Cyprus and Greece form a distinct group at the top of the ranking with significantly higher performances than other countries (see table 2). Poland follows next. Then there is a large group of countries (from Slovakia to Sweden), which show hardly any withingroup significant differences in the pairwise comparisons. Next, is another substantial group of countries (from Denmark to Czech Republic), which cannot be distinguished from each other in terms of the CCCI. The lowest ranking includes a group of three countries, Belgium (Fr), Latvia, and Estonia.

\section{The Four Domains}

In reviewing the rankings related to the four domains, (Greek-speaking) Cyprus and Greece appear at the top in all the domains. In the middle and at the bottom of the rankings there is less consistency. We discuss the rankings for each domain below.

\section{Citizenship Values}

The ranking in this domain is headed by Greece and (Greek-speaking) Cyprus, which score significantly higher than all the other countries (see table 3). They are followed by Romania and Lithuania and then by a larger group from Poland to Bulgaria. Next is a large group of countries from Hungary to the Czech Republic. The lowest ranking includes five countries 
TABLE 2

Statistical Significance, Pairwise Comparison Country Scores, and Civic Competence Composite Indicator (CCCI)

\begin{tabular}{|c|c|c|c|c|c|c|c|c|c|c|c|c|c|c|c|c|c|c|c|c|c|c|c|c|c|}
\hline & Avg. & SD & CYP & GRC & POL & SVK & PRT & NOR & ITA & ROM & SWE & DNK & FIN & ENG & LTU & SVN & HUN & DEU & CHE & BGR & RUS & CZE & BFR & LVA & EST \\
\hline CYP & 642 & 102 & - & - & $\Delta$ & $\boldsymbol{\Delta}$ & $\Delta$ & $\Delta$ & $\Delta$ & $\Delta$ & $\Delta$ & $\Delta$ & $\boldsymbol{\Delta}$ & $\boldsymbol{\Delta}$ & $\boldsymbol{\Delta}$ & $\Delta$ & $\boldsymbol{\Delta}$ & $\boldsymbol{\Delta}$ & $\Delta$ & $\Delta$ & $\boldsymbol{\Delta}$ & $\Delta$ & $\boldsymbol{\Delta}$ & $\Delta$ & $\boldsymbol{\Delta}$ \\
\hline GRC & 623 & 112 & - & - & $\Delta$ & $\boldsymbol{\Delta}$ & $\Delta$ & $\boldsymbol{\Delta}$ & $\boldsymbol{\Delta}$ & $\boldsymbol{\Delta}$ & $\Delta$ & $\Delta$ & $\boldsymbol{\Delta}$ & $\boldsymbol{\Delta}$ & $\boldsymbol{\Delta}$ & $\Delta$ & $\Delta$ & $\boldsymbol{\Delta}$ & $\Delta$ & $\Delta$ & $\boldsymbol{\Delta}$ & $\Delta$ & $\boldsymbol{\Delta}$ & $\Delta$ & $\boldsymbol{\Delta}$ \\
\hline POL & 594 & 107 & $\nabla$ & $\nabla$ & - & $\boldsymbol{\Delta}$ & $\boldsymbol{\Delta}$ & $\Delta$ & $\Delta$ & $\Delta$ & $\boldsymbol{\Delta}$ & $\Delta$ & $\Delta$ & $\boldsymbol{\Delta}$ & $\boldsymbol{\Delta}$ & $\Delta$ & $\boldsymbol{\Delta}$ & $\Delta$ & $\boldsymbol{\Delta}$ & $\Delta$ & $\boldsymbol{\Delta}$ & $\Delta$ & $\boldsymbol{\Delta}$ & $\Delta$ & $\boldsymbol{\Delta}$ \\
\hline SVK & 569 & 93 & $\nabla$ & $\boldsymbol{\nabla}$ & $\nabla$ & - & - & - & - & - & $\Delta$ & $\Delta$ & $\boldsymbol{\Delta}$ & $\boldsymbol{\Delta}$ & $\boldsymbol{\Delta}$ & $\Delta$ & $\Delta$ & $\Delta$ & $\Delta$ & $\Delta$ & $\boldsymbol{\Delta}$ & $\Delta$ & $\Delta$ & $\boldsymbol{\Delta}$ & $\boldsymbol{\Delta}$ \\
\hline PRT & 565 & 98 & $\boldsymbol{\nabla}$ & $\nabla$ & $\nabla$ & - & - & - & - & - & $\Delta$ & $\Delta$ & $\boldsymbol{\Delta}$ & $\boldsymbol{\Delta}$ & $\boldsymbol{\Delta}$ & $\Delta$ & $\Delta$ & $\Delta$ & $\Delta$ & $\Delta$ & $\boldsymbol{\Delta}$ & $\Delta$ & $\Delta$ & $\Delta$ & $\boldsymbol{\Delta}$ \\
\hline NOR & 562 & 110 & $\nabla$ & $\boldsymbol{\nabla}$ & $\nabla$ & - & - & - & - & - & $\Delta$ & $\Delta$ & $\boldsymbol{\Delta}$ & $\boldsymbol{\Delta}$ & $\boldsymbol{\Delta}$ & $\boldsymbol{\Delta}$ & $\Delta$ & $\Delta$ & $\boldsymbol{\Delta}$ & $\Delta$ & $\boldsymbol{\Delta}$ & $\boldsymbol{\Delta}$ & $\boldsymbol{\Delta}$ & $\boldsymbol{\Delta}$ & $\boldsymbol{\Delta}$ \\
\hline ITA & 560 & 103 & $\nabla$ & $\boldsymbol{\nabla}$ & $\nabla$ & - & - & - & - & - & • & $\Delta$ & $\boldsymbol{\Delta}$ & $\boldsymbol{\Delta}$ & $\boldsymbol{\Delta}$ & $\Delta$ & $\Delta$ & $\Delta$ & $\Delta$ & $\Delta$ & $\Delta$ & $\Delta$ & $\boldsymbol{\Delta}$ & $\Delta$ & $\boldsymbol{\Delta}$ \\
\hline ROM & 558 & 98 & $\nabla$ & $\boldsymbol{\nabla}$ & $\nabla$ & - & • & - & - & - & - & $\Delta$ & $\boldsymbol{\Delta}$ & $\boldsymbol{\Delta}$ & $\boldsymbol{\Delta}$ & $\Delta$ & $\Delta$ & $\boldsymbol{\Delta}$ & $\Delta$ & $\Delta$ & $\Delta$ & $\Delta$ & $\boldsymbol{\Delta}$ & $\Delta$ & $\boldsymbol{\Delta}$ \\
\hline SWE & 541 & 110 & $\boldsymbol{\nabla}$ & $\boldsymbol{\nabla}$ & $\nabla$ & $\nabla$ & $\nabla$ & $\nabla$ & - & - & - & • & - & • & • & - & • & - & • & $\Delta$ & $\boldsymbol{\Delta}$ & $\Delta$ & $\boldsymbol{\Delta}$ & $\Delta$ & $\boldsymbol{\Delta}$ \\
\hline DNK & 535 & 106 & $\boldsymbol{\nabla}$ & $\boldsymbol{\nabla}$ & $\nabla$ & $\nabla$ & $\nabla$ & $\nabla$ & $\nabla$ & $\nabla$ & - & - & - & - & - & - & - & - & - & • & • & • & $\Delta$ & $\Delta$ & $\Delta$ \\
\hline FIN & 533 & 100 & $\nabla$ & $\boldsymbol{\nabla}$ & $\nabla$ & $\nabla$ & $\boldsymbol{\nabla}$ & $\nabla$ & $\nabla$ & $\nabla$ & - & • & - & - & • & - & - & - & - & - & - & - & $\Delta$ & $\Delta$ & $\Delta$ \\
\hline ENG & 533 & 106 & $\boldsymbol{\nabla}$ & $\nabla$ & $\nabla$ & $\boldsymbol{\nabla}$ & $\nabla$ & $\boldsymbol{\nabla}$ & $\nabla$ & $\nabla$ & - & - & - & - & • & • & • & • & • & • & • & • & $\boldsymbol{\Delta}$ & $\Delta$ & $\Delta$ \\
\hline LTU & 533 & 92 & $\nabla$ & $\nabla$ & $\nabla$ & $\nabla$ & $\nabla$ & $\nabla$ & $\nabla$ & $\nabla$ & • & - & • & • & - & • & - & • & • & • & • & • & $\boldsymbol{\Delta}$ & $\boldsymbol{\Delta}$ & $\Delta$ \\
\hline SVN & 524 & 94 & $\nabla$ & $\nabla$ & $\nabla$ & $\nabla$ & $\nabla$ & $\nabla$ & $\nabla$ & $\nabla$ & - & - & - & - & • & - & - & - & - & • & - & • & • & $\Delta$ & $\Delta$ \\
\hline HUN & 523 & 87 & $\nabla$ & $\nabla$ & $\nabla$ & $\nabla$ & $\nabla$ & $\nabla$ & $\nabla$ & $\nabla$ & - & - & - & • & • & - & - & - & • & • & • & • & - & $\Delta$ & $\boldsymbol{\Delta}$ \\
\hline DEU & 521 & 98 & $\nabla$ & $\nabla$ & $\nabla$ & $\nabla$ & $\nabla$ & $\nabla$ & $\nabla$ & $\nabla$ & • & - & - & - & • & - & - & - & • & • & • & • & - & • & $\boldsymbol{\Delta}$ \\
\hline CHE & 520 & 94 & $\nabla$ & $\nabla$ & $\nabla$ & $\nabla$ & $\nabla$ & $\nabla$ & $\nabla$ & $\nabla$ & • & • & - & - & • & • & - & - & - & • & • & • & - & - & $\Delta$ \\
\hline BGR & 519 & 109 & $\nabla$ & $\nabla$ & $\nabla$ & $\nabla$ & $\nabla$ & $\nabla$ & $\nabla$ & $\nabla$ & $\nabla$ & • & • & • & • & • & • & • & • & - & • & • & • & - & $\boldsymbol{\Delta}$ \\
\hline RUS & 519 & 87 & $\nabla$ & $\nabla$ & $\nabla$ & $\nabla$ & $\nabla$ & $\nabla$ & $\nabla$ & $\nabla$ & $\nabla$ & • & - & • & • & • & • & • & - & • & - & • & • & - & $\boldsymbol{\Delta}$ \\
\hline CZE & 516 & 95 & $\nabla$ & $\nabla$ & $\nabla$ & $\nabla$ & $\nabla$ & $\nabla$ & $\nabla$ & $\nabla$ & $\nabla$ & • & • & • & • & - & - & • & - & - & • & - & - & - & $\boldsymbol{\Delta}$ \\
\hline BFR & 512 & 107 & $\nabla$ & $\nabla$ & $\nabla$ & $\nabla$ & $\nabla$ & $\nabla$ & $\boldsymbol{\nabla}$ & $\nabla$ & $\nabla$ & $\nabla$ & $\nabla$ & $\nabla$ & $\nabla$ & - & - & • & - & • & • & - & - & • & - \\
\hline LVA & 502 & 87 & $\nabla$ & $\nabla$ & $\nabla$ & $\boldsymbol{\nabla}$ & $\nabla$ & $\nabla$ & $\boldsymbol{\nabla}$ & $\nabla$ & $\boldsymbol{\nabla}$ & $\nabla$ & $\nabla$ & $\nabla$ & $\nabla$ & $\nabla$ & $\nabla$ & - & - & • & • & • & - & - & - \\
\hline EST & 494 & 86 & $\nabla$ & $\nabla$ & $\nabla$ & $\nabla$ & $\nabla$ & $\nabla$ & $\boldsymbol{\nabla}$ & $\nabla$ & $\nabla$ & $\nabla$ & $\nabla$ & $\nabla$ & $\nabla$ & $\boldsymbol{\nabla}$ & $\nabla$ & $\nabla$ & $\nabla$ & $\nabla$ & $\nabla$ & $\nabla$ & - & • & - \\
\hline
\end{tabular}


TABLE 3

Statistical Significance, Pairwise Comparison Country Scores, and Citizenship Values

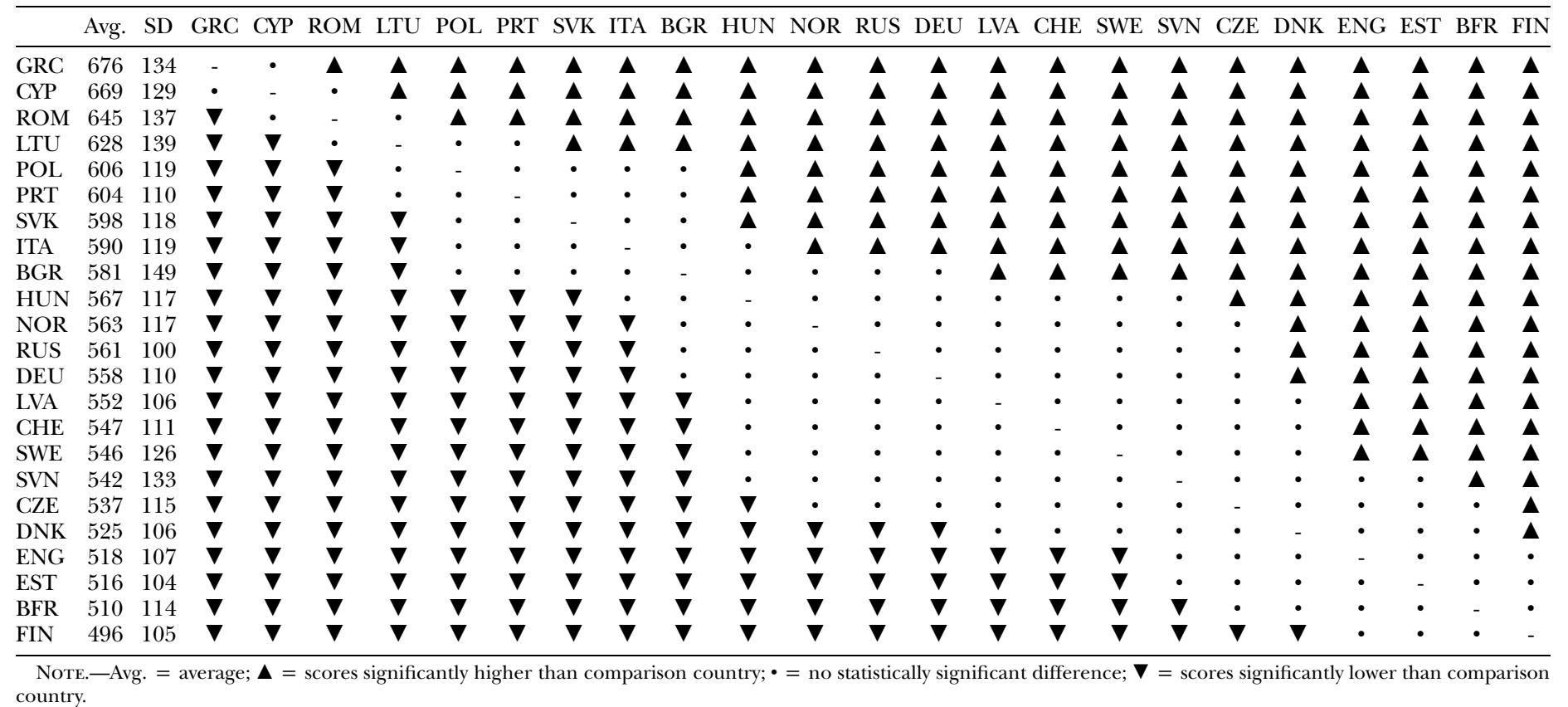


(Denmark, England, Estonia, Belgium [Fr], and Finland), which do not show any substantial within-group differences, but all score substantially lower than the other countries.

Social Justice Values and Attitudes

For this domain, (Greek-speaking) Cyprus clearly outperforms all other countries (see table 4). Next is a group of countries from Portugal to Greece. These countries are followed by the three Nordic countries (Sweden, Denmark, and Finland). The next group is a large cluster of countries (from Belgium [Fr] to Germany). Four countries (Russia, Hungary, Bulgaria, and Latvia) are included in the lowest ranking.

\section{Participatory Attitudes}

(Greek-speaking) Cyprus appears at the top again in the results on this domain and is followed by a group ranging from Greece to Slovakia (see table 5). ${ }^{8}$ Next there is a large group of countries (from Italy to Belgium $[\mathrm{Fr}]$ ). Finally, we observe a rather large group of low-scoring countries (from Bulgaria to Czech Republic).

Cognition and Democratic Institutions

The ranking in this domain is headed by a group of five countries, with (Greek-speaking) Cyprus on top, but now joined by Greece, Finland, Slovakia, and Italy (see table 6). This group is followed by Sweden, Norway, and then by a group of five countries (from Czech Republic to Switzerland). Next are two smaller groups of countries: $(a)$ Slovenia to Belgium (Fr) and then $(b)$ Portugal, Estonia, and Romania. Two Baltic states (Lithuania and Latvia) are in the lowest ranking.

\section{Discussion}

\section{Country Rankings on CCCI}

Here we provide contextual explanations for the results, drawing on previous comparative research in the field of political science (Almond and Verba 1963; Inglehart and Welzel 2005) and citizenship education research (Han 1998), the IEA CIVED case study book (Torney-Purta et al. 1999), and expertise from researchers and policy makers in the countries where the study took place. These explanations, however, are preliminary and require further investigation.

Contrary to either direction of our hypothesis on years of democracy, and contrary to what would be expected from the influences of either civic/ ethnic understandings of citizenship, economic prosperity, or civic education, the results for the CCCI gives us a mixed pattern of results with no obvious al. 2008).

${ }^{8}$ This group shows some significant, but very small, differences in the effect sizes (see Hoskins et 
TABLE 4

Statistical Significance Pairwise Comparison of Country Scores, Social Justice

\begin{tabular}{|c|c|c|c|c|c|c|c|c|c|c|c|c|c|c|c|c|c|c|c|c|c|c|c|c|c|}
\hline & Avg. & SD & CYP & PRT & NOR & ENG & POL & GRC & SWE & DNK & FIN & BFR & LTU & CZE & CHE & ITA & SVK & ROM & EST & SVN & DEU & RUS & HUN & BGR & LVA \\
\hline CYP & 707 & 144 & - & $\Delta$ & $\boldsymbol{\Delta}$ & $\boldsymbol{\Delta}$ & $\boldsymbol{\Delta}$ & $\boldsymbol{\Delta}$ & $\boldsymbol{\Delta}$ & $\boldsymbol{\Delta}$ & $\Delta$ & $\boldsymbol{\Delta}$ & $\boldsymbol{\Delta}$ & $\boldsymbol{\Delta}$ & $\Delta$ & $\Delta$ & $\boldsymbol{\Delta}$ & $\boldsymbol{\Delta}$ & $\boldsymbol{\Delta}$ & $\boldsymbol{\Delta}$ & $\Delta$ & $\Delta$ & $\Delta$ & $\boldsymbol{\Delta}$ & $\boldsymbol{\Delta}$ \\
\hline PRT & 680 & 140 & $\nabla$ & - & - & • & • & • & $\boldsymbol{\Delta}$ & $\boldsymbol{\Delta}$ & $\Delta$ & $\boldsymbol{\Delta}$ & $\boldsymbol{\Delta}$ & $\boldsymbol{\Delta}$ & $\Delta$ & $\Delta$ & $\boldsymbol{\Delta}$ & $\boldsymbol{\Delta}$ & $\boldsymbol{\Delta}$ & $\boldsymbol{\Delta}$ & $\Delta$ & $\Delta$ & $\Delta$ & $\Delta$ & $\boldsymbol{\Delta}$ \\
\hline NOR & 678 & 153 & $\nabla$ & - & - & - & - & - & $\boldsymbol{\Delta}$ & $\boldsymbol{\Delta}$ & $\Delta$ & $\boldsymbol{\Delta}$ & $\Delta$ & $\Delta$ & $\Delta$ & $\Delta$ & $\boldsymbol{\Delta}$ & $\Delta$ & $\boldsymbol{\Delta}$ & $\Delta$ & $\Delta$ & $\Delta$ & $\Delta$ & $\Delta$ & $\boldsymbol{\Delta}$ \\
\hline ENG & 671 & 157 & $\nabla$ & - & - & - & - & - & • & - & $\Delta$ & $\Delta$ & $\Delta$ & $\boldsymbol{\Delta}$ & $\Delta$ & $\Delta$ & $\Delta$ & $\boldsymbol{\Delta}$ & $\boldsymbol{\Delta}$ & $\Delta$ & $\Delta$ & $\Delta$ & $\Delta$ & $\Delta$ & $\boldsymbol{\Delta}$ \\
\hline POL & 668 & 154 & $\boldsymbol{\nabla}$ & - & - & - & - & - & - & - & - & $\Delta$ & $\boldsymbol{\Delta}$ & $\boldsymbol{\Delta}$ & $\Delta$ & $\Delta$ & $\boldsymbol{\Delta}$ & $\boldsymbol{\Delta}$ & $\boldsymbol{\Delta}$ & $\Delta$ & $\Delta$ & $\Delta$ & $\Delta$ & $\Delta$ & $\boldsymbol{\Delta}$ \\
\hline GRC & 667 & 149 & $\nabla$ & - & - & - & - & - & - & - & - & $\Delta$ & $\Delta$ & $\boldsymbol{\Delta}$ & $\boldsymbol{\Delta}$ & $\boldsymbol{\Delta}$ & $\boldsymbol{\Delta}$ & $\Delta$ & $\Delta$ & $\Delta$ & $\boldsymbol{\Delta}$ & $\Delta$ & $\boldsymbol{\Delta}$ & $\Delta$ & $\boldsymbol{\Delta}$ \\
\hline SWE & 655 & 148 & $\nabla$ & $\nabla$ & $\boldsymbol{\nabla}$ & - & - & - & - & - & - & $\Delta$ & $\Delta$ & $\boldsymbol{\Delta}$ & $\Delta$ & $\Delta$ & $\boldsymbol{\Delta}$ & $\boldsymbol{\Delta}$ & $\Delta$ & $\boldsymbol{\Delta}$ & $\Delta$ & $\Delta$ & $\boldsymbol{\Delta}$ & $\Delta$ & $\boldsymbol{\Delta}$ \\
\hline DNK & 654 & 150 & $\nabla$ & $\boldsymbol{\nabla}$ & $\boldsymbol{\nabla}$ & - & - & - & - & - & - & $\Delta$ & $\Delta$ & $\boldsymbol{\Delta}$ & $\Delta$ & $\Delta$ & $\boldsymbol{\Delta}$ & $\boldsymbol{\Delta}$ & $\Delta$ & $\boldsymbol{\Delta}$ & $\Delta$ & $\Delta$ & $\boldsymbol{\Delta}$ & $\Delta$ & $\boldsymbol{\Delta}$ \\
\hline FIN & 649 & 141 & $\nabla$ & $\boldsymbol{\nabla}$ & $\boldsymbol{\nabla}$ & $\nabla$ & - & • & • & • & - & - & $\boldsymbol{\Delta}$ & $\Delta$ & $\Delta$ & $\Delta$ & $\boldsymbol{\Delta}$ & $\boldsymbol{\Delta}$ & $\boldsymbol{\Delta}$ & $\Delta$ & $\Delta$ & $\Delta$ & $\boldsymbol{\Delta}$ & $\boldsymbol{\Delta}$ & $\boldsymbol{\Delta}$ \\
\hline BFR & 630 & 162 & $\nabla$ & $\nabla$ & $\nabla$ & $\nabla$ & $\nabla$ & $\nabla$ & $\nabla$ & $\nabla$ & • & - & - & • & • & - & • & • & $\boldsymbol{\Delta}$ & $\boldsymbol{\Delta}$ & $\Delta$ & $\Delta$ & $\Delta$ & $\boldsymbol{\Delta}$ & $\boldsymbol{\Delta}$ \\
\hline LTU & 620 & 128 & $\nabla$ & $\boldsymbol{\nabla}$ & $\nabla$ & $\nabla$ & $\nabla$ & $\nabla$ & $\boldsymbol{\nabla}$ & $\nabla$ & $\nabla$ & - & - & - & - & - & - & - & - & • & • & $\Delta$ & $\Delta$ & $\Delta$ & $\boldsymbol{\Delta}$ \\
\hline CZE & 617 & 126 & $\boldsymbol{\nabla}$ & $\boldsymbol{\nabla}$ & $\nabla$ & $\nabla$ & $\nabla$ & $\nabla$ & $\boldsymbol{\nabla}$ & $\nabla$ & $\boldsymbol{\nabla}$ & - & - & - & • & - & - & • & - & • & • & $\Delta$ & $\boldsymbol{\Delta}$ & $\boldsymbol{\Delta}$ & $\Delta$ \\
\hline CHE & 616 & 142 & $\nabla$ & $\boldsymbol{\nabla}$ & $\nabla$ & $\nabla$ & $\nabla$ & $\nabla$ & $\nabla$ & $\nabla$ & $\nabla$ & - & • & - & - & - & • & • & - & • & • & $\Delta$ & $\Delta$ & $\Delta$ & $\boldsymbol{\Delta}$ \\
\hline ITA & 616 & 132 & $\nabla$ & $\nabla$ & $\nabla$ & $\boldsymbol{\nabla}$ & $\nabla$ & $\nabla$ & $\nabla$ & $\nabla$ & $\nabla$ & - & - & - & - & - & - & • & - & - & • & $\Delta$ & $\Delta$ & $\Delta$ & $\boldsymbol{\Delta}$ \\
\hline SVK & 616 & 122 & $\boldsymbol{\nabla}$ & $\nabla$ & $\nabla$ & $\boldsymbol{\nabla}$ & $\nabla$ & $\nabla$ & $\nabla$ & $\nabla$ & $\nabla$ & - & • & - & • & • & - & • & • & • & • & $\Delta$ & $\Delta$ & $\Delta$ & $\Delta$ \\
\hline ROM & 613 & 135 & $\nabla$ & $\nabla$ & $\nabla$ & $\nabla$ & $\nabla$ & $\nabla$ & $\nabla$ & $\nabla$ & $\nabla$ & - & • & • & • & • & • & - & • & - & - & • & $\Delta$ & $\Delta$ & $\Delta$ \\
\hline EST & 608 & 117 & $\nabla$ & $\nabla$ & $\nabla$ & $\nabla$ & $\nabla$ & $\nabla$ & $\nabla$ & $\nabla$ & $\nabla$ & $\nabla$ & • & - & • & - & • & • & - & - & • & • & $\boldsymbol{\Delta}$ & $\Delta$ & $\boldsymbol{\Delta}$ \\
\hline SVN & 604 & 132 & $\nabla$ & $\nabla$ & $\nabla$ & $\nabla$ & $\nabla$ & $\nabla$ & $\nabla$ & $\nabla$ & $\nabla$ & $\nabla$ & • & • & • & • & • & • & • & - & • & • & • & • & $\Delta$ \\
\hline DEU & 603 & 140 & $\nabla$ & $\boldsymbol{\nabla}$ & $\nabla$ & $\nabla$ & $\nabla$ & $\nabla$ & $\nabla$ & $\nabla$ & $\nabla$ & $\nabla$ & - & - & • & • & • & • & • & • & - & • & • & • & $\boldsymbol{\Delta}$ \\
\hline RUS & 593 & 116 & $\nabla$ & $\nabla$ & $\nabla$ & $\nabla$ & $\nabla$ & $\nabla$ & $\nabla$ & $\nabla$ & $\nabla$ & $\nabla$ & $\nabla$ & $\nabla$ & $\nabla$ & $\nabla$ & $\nabla$ & • & - & • & - & - & • & - & $\Delta$ \\
\hline HUN & 586 & 119 & $\nabla$ & $\nabla$ & $\nabla$ & $\nabla$ & $\nabla$ & $\nabla$ & $\nabla$ & $\nabla$ & $\nabla$ & $\nabla$ & $\nabla$ & $\nabla$ & $\nabla$ & $\nabla$ & $\nabla$ & $\nabla$ & $\nabla$ & • & • & - & - & • & - \\
\hline BGR & 583 & 154 & $\nabla$ & $\boldsymbol{\nabla}$ & $\nabla$ & $\nabla$ & $\nabla$ & $\nabla$ & $\nabla$ & $\nabla$ & $\nabla$ & $\nabla$ & $\nabla$ & $\nabla$ & $\nabla$ & $\nabla$ & $\nabla$ & $\nabla$ & $\nabla$ & - & • & - & - & - & - \\
\hline LVA & 571 & 116 & $\nabla$ & $\boldsymbol{\nabla}$ & $\nabla$ & $\nabla$ & $\boldsymbol{\nabla}$ & $\nabla$ & $\nabla$ & $\nabla$ & $\boldsymbol{\nabla}$ & $\nabla$ & $\nabla$ & $\nabla$ & $\nabla$ & $\nabla$ & $\nabla$ & $\nabla$ & $\nabla$ & $\nabla$ & $\nabla$ & $\nabla$ & - & • & - \\
\hline
\end{tabular}


TABLE 5

Statistical Significance, Pairwise Comparison Country Scores, and Participatory Attitudes

\begin{tabular}{|c|c|c|c|c|c|c|c|c|c|c|c|c|c|c|c|c|c|c|c|c|c|c|c|c|c|}
\hline & Avg. & SD & CYP & GRC & ROM & POL & PRT & SVK & ITA & LVA & SVN & HUN & NOR & RUS & BFR & BGR & DNK & LTU & ENG & DEU & CHE & EST & FIN & SWE & CZE \\
\hline CYP & 613 & 130 & - & $\Delta$ & $\Delta$ & $\Delta$ & $\Delta$ & $\Delta$ & $\Delta$ & $\Delta$ & $\Delta$ & $\Delta$ & $\Delta$ & $\Delta$ & $\Delta$ & $\Delta$ & $\Delta$ & $\Delta$ & $\Delta$ & $\Delta$ & $\Delta$ & $\Delta$ & $\Delta$ & $\Delta$ & $\Delta$ \\
\hline GRC & 572 & 129 & $\nabla$ & - & • & • & $\bar{\Delta}$ & $\bar{\Delta}$ & $\bar{\Delta}$ & $\bar{\Delta}$ & $\bar{\Delta}$ & $\bar{\Delta}$ & $\bar{\Delta}$ & $\bar{\Delta}$ & $\bar{\Delta}$ & $\bar{\Delta}$ & $\bar{\Delta}$ & $\bar{\Delta}$ & $\bar{\Delta}$ & $\bar{\Delta}$ & $\bar{\Delta}$ & $\bar{\Delta}$ & $\bar{\Delta}$ & $\bar{\Delta}$ & $\bar{\Delta}$ \\
\hline ROM & 558 & 133 & $\nabla$ & • & - & - & - & • & $\boldsymbol{\Delta}$ & $\boldsymbol{\Delta}$ & $\boldsymbol{\Delta}$ & $\boldsymbol{\Delta}$ & $\boldsymbol{\Delta}$ & $\boldsymbol{\Delta}$ & $\boldsymbol{\Delta}$ & $\Delta$ & $\boldsymbol{\Delta}$ & $\boldsymbol{\Delta}$ & $\boldsymbol{\Delta}$ & $\Delta$ & $\boldsymbol{\Delta}$ & $\boldsymbol{\Delta}$ & $\boldsymbol{\Delta}$ & $\boldsymbol{\Delta}$ & $\boldsymbol{\Delta}$ \\
\hline POL & 550 & 143 & $\nabla$ & - & - & - & - & - & $\Delta$ & $\Delta$ & $\Delta$ & $\Delta$ & $\Delta$ & $\Delta$ & $\Delta$ & $\Delta$ & $\Delta$ & $\Delta$ & $\Delta$ & $\Delta$ & $\Delta$ & $\Delta$ & $\Delta$ & $\Delta$ & $\Delta$ \\
\hline PRT & 540 & 126 & $\nabla$ & $\boldsymbol{\nabla}$ & - & - & - & - & $\boldsymbol{\Delta}$ & $\Delta$ & $\Delta$ & $\boldsymbol{\Delta}$ & $\boldsymbol{\Delta}$ & $\boldsymbol{\Delta}$ & $\boldsymbol{\Delta}$ & $\boldsymbol{\Delta}$ & $\boldsymbol{\Delta}$ & $\Delta$ & $\boldsymbol{\Delta}$ & $\Delta$ & $\Delta$ & $\Delta$ & $\boldsymbol{\Delta}$ & $\boldsymbol{\Delta}$ & $\boldsymbol{\Delta}$ \\
\hline SVK & 539 & 126 & $\nabla$ & $\nabla$ & - & - & - & - & $\bar{\Delta}$ & $\bar{\Delta}$ & $\Delta$ & $\bar{\Delta}$ & $\Delta$ & $\bar{\Delta}$ & $\bar{\Delta}$ & $\bar{\Delta}$ & $\bar{\Delta}$ & $\overline{\mathbf{A}}$ & $\bar{\Delta}$ & $\bar{\Delta}$ & $\bar{\Delta}$ & $\bar{\Delta}$ & $\bar{\Delta}$ & $\bar{\Delta}$ & $\bar{\Delta}$ \\
\hline ITA & 511 & 133 & $\nabla$ & $\nabla$ & $\nabla$ & $\nabla$ & $\nabla$ & $\nabla$ & - & - & - & - & - & - & $\Delta$ & $\Delta$ & $\Delta$ & $\Delta$ & $\Delta$ & $\Delta$ & $\Delta$ & $\Delta$ & $\Delta$ & $\Delta$ & $\Delta$ \\
\hline LVA & 503 & 141 & $\nabla$ & $\nabla$ & $\nabla$ & $\nabla$ & $\nabla$ & $\nabla$ & - & - & - & - & - & - & • & $\Delta$ & $\Delta$ & $\Delta$ & $\Delta$ & $\Delta$ & $\Delta$ & $\Delta$ & $\Delta$ & $\Delta$ & $\Delta$ \\
\hline SVN & 495 & 128 & $\nabla$ & $\nabla$ & $\nabla$ & $\nabla$ & $\nabla$ & $\nabla$ & - & - & - & - & - & - & - & - & - & • & $\Delta$ & $\Delta$ & $\Delta$ & $\Delta$ & $\Delta$ & $\Delta$ & $\Delta$ \\
\hline HUN & 493 & 126 & $\nabla$ & $\nabla$ & $\nabla$ & $\nabla$ & $\nabla$ & $\nabla$ & - & - & - & - & - & - & - & - & - & - & $\Delta$ & $\Delta$ & $\Delta$ & $\Delta$ & $\Delta$ & $\Delta$ & $\Delta$ \\
\hline NOR & 490 & 149 & $\nabla$ & $\nabla$ & $\nabla$ & $\nabla$ & $\nabla$ & $\nabla$ & - & - & - & - & - & - & - & - & - & - & - & $\Delta$ & $\Delta$ & $\Delta$ & $\Delta$ & $\Delta$ & $\Delta$ \\
\hline RUS & 490 & 133 & $\nabla$ & $\boldsymbol{\nabla}$ & $\nabla$ & $\nabla$ & $\nabla$ & $\nabla$ & - & - & - & - & - & - & • & - & - & - & - & $\Delta$ & $\Delta$ & $\Delta$ & $\Delta$ & $\Delta$ & $\Delta$ \\
\hline BFR & 481 & 142 & $\nabla$ & $\nabla$ & $\nabla$ & $\nabla$ & $\nabla$ & $\nabla$ & $\nabla$ & - & - & - & - & - & - & - & - & - & - & - & - & • & $\Delta$ & $\Delta$ & $\Delta$ \\
\hline BGR & 475 & 145 & $\nabla$ & $\boldsymbol{\nabla}$ & $\nabla$ & $\nabla$ & $\nabla$ & $\boldsymbol{\nabla}$ & $\nabla$ & $\nabla$ & - & - & - & - & • & - & • & - & - & • & • & - & • & $\Delta$ & $\Delta$ \\
\hline DNK & 474 & 144 & $\nabla$ & $\nabla$ & $\nabla$ & $\nabla$ & $\nabla$ & $\nabla$ & $\nabla$ & $\nabla$ & • & - & • & - & • & - & - & - & - & • & • & - & • & $\Delta$ & $\Delta$ \\
\hline LTU & 471 & 137 & $\nabla$ & $\nabla$ & $\nabla$ & $\nabla$ & $\nabla$ & $\nabla$ & $\nabla$ & $\nabla$ & • & • & • & - & • & • & • & - & • & • & - & - & • & • & $\Delta$ \\
\hline ENG & 464 & 154 & $\nabla$ & $\nabla$ & $\nabla$ & $\nabla$ & $\nabla$ & $\nabla$ & $\nabla$ & $\nabla$ & $\nabla$ & $\nabla$ & • & • & • & - & • & - & - & - & - & - & - & - & • \\
\hline DEU & 462 & 140 & $\nabla$ & $\nabla$ & $\nabla$ & $\nabla$ & $\nabla$ & $\nabla$ & $\nabla$ & $\nabla$ & $\nabla$ & $\nabla$ & $\nabla$ & $\nabla$ & • & - & • & • & • & - & • & • & • & • & • \\
\hline CHE & 456 & 140 & $\nabla$ & $\nabla$ & $\nabla$ & $\nabla$ & $\nabla$ & $\nabla$ & $\nabla$ & $\nabla$ & $\nabla$ & $\nabla$ & $\nabla$ & $\nabla$ & • & • & • & • & • & • & - & - & • & • & • \\
\hline EST & 456 & 135 & $\nabla$ & $\nabla$ & $\nabla$ & $\nabla$ & $\nabla$ & $\nabla$ & $\nabla$ & $\nabla$ & $\nabla$ & $\nabla$ & $\nabla$ & $\nabla$ & • & - & • & • & • & • & • & - & • & • & • \\
\hline FIN & 454 & 136 & $\nabla$ & $\nabla$ & $\nabla$ & $\nabla$ & $\nabla$ & $\nabla$ & $\nabla$ & $\nabla$ & $\nabla$ & $\nabla$ & $\nabla$ & $\nabla$ & $\nabla$ & • & • & • & • & - & • & • & - & - & • \\
\hline SWE & 447 & 152 & $\nabla$ & $\nabla$ & $\nabla$ & $\nabla$ & $\nabla$ & $\nabla$ & $\nabla$ & $\nabla$ & $\nabla$ & $\nabla$ & $\nabla$ & $\nabla$ & $\nabla$ & $\nabla$ & $\nabla$ & - & • & - & • & • & • & - & • \\
\hline CZE & 443 & 130 & $\nabla$ & $\nabla$ & $\nabla$ & $\nabla$ & $\nabla$ & $\nabla$ & $\nabla$ & $\nabla$ & $\nabla$ & $\nabla$ & $\nabla$ & $\nabla$ & $\nabla$ & $\nabla$ & $\nabla$ & $\nabla$ & • & - & • & • & • & • & - \\
\hline
\end{tabular}


TABLE 6

Statistical Significance, Pairwise Comparison Country Scores, and Cognitions about Democratic Institutions

\begin{tabular}{|c|c|c|c|c|c|c|c|c|c|c|c|c|c|c|c|c|c|c|c|c|c|c|c|c|c|}
\hline & Avg. & SD & CYP & GRC & FIN & POL & SVK & ITA & SWE & NOR & CZE & ENG & DNK & DEU & CHE & SVN & HUN & RUS & BGR & BFR & PRT & EST & ROM & LTU & LVA \\
\hline CYP & 595 & 102 & - & - & - & - & - & - & $\Delta$ & $\Delta$ & $\Delta$ & $\boldsymbol{\Delta}$ & $\Delta$ & $\Delta$ & $\Delta$ & $\Delta$ & $\Delta$ & $\Delta$ & $\boldsymbol{\Delta}$ & $\boldsymbol{\Delta}$ & $\Delta$ & $\Delta$ & $\Delta$ & $\Delta$ & $\Delta$ \\
\hline GRC & 593 & 112 & • & - & • & • & • & • & $\boldsymbol{\Delta}$ & $\bar{\Delta}$ & $\boldsymbol{\Delta}$ & $\bar{\Delta}$ & $\boldsymbol{\Delta}$ & $\Delta$ & $\bar{\Delta}$ & $\bar{\Delta}$ & $\Delta$ & $\bar{\Delta}$ & $\Delta$ & $\bar{\Delta}$ & $\Delta$ & $\bar{\Delta}$ & $\bar{\Delta}$ & $\bar{\Delta}$ & $\bar{\Delta}$ \\
\hline FIN & 587 & 100 & - & - & - & - & - & - & $\Delta$ & $\Delta$ & $\Delta$ & $\Delta$ & $\Delta$ & $\Delta$ & $\Delta$ & $\Delta$ & $\Delta$ & $\Delta$ & $\Delta$ & $\Delta$ & $\Delta$ & $\Delta$ & $\Delta$ & $\Delta$ & $\Delta$ \\
\hline POL & 583 & 107 & - & • & - & - & - & - & $\Delta$ & $\Delta$ & $\Delta$ & $\Delta$ & $\Delta$ & $\Delta$ & $\Delta$ & $\Delta$ & $\Delta$ & $\Delta$ & $\Delta$ & $\Delta$ & $\Delta$ & $\Delta$ & $\Delta$ & $\Delta$ & $\Delta$ \\
\hline SVK & 571 & 93 & - & • & - & - & - & - & • & - & $\Delta$ & $\Delta$ & $\Delta$ & $\Delta$ & $\Delta$ & $\Delta$ & $\Delta$ & $\Delta$ & $\Delta$ & $\Delta$ & $\Delta$ & $\boldsymbol{\Delta}$ & $\Delta$ & $\Delta$ & $\Delta$ \\
\hline ITA & 565 & 103 & - & • & - & • & - & - & - & - & • & $\Delta$ & $\boldsymbol{\Delta}$ & $\Delta$ & $\Delta$ & $\Delta$ & $\Delta$ & $\Delta$ & $\Delta$ & $\Delta$ & $\Delta$ & $\Delta$ & $\Delta$ & $\Delta$ & $\Delta$ \\
\hline SWE & 552 & 110 & $\nabla$ & $\nabla$ & $\nabla$ & $\nabla$ & - & - & - & - & - & • & - & • & • & $\Delta$ & $\Delta$ & $\Delta$ & $\Delta$ & $\boldsymbol{\Delta}$ & $\Delta$ & $\Delta$ & $\Delta$ & $\Delta$ & $\Delta$ \\
\hline NOR & 549 & 110 & $\nabla$ & $\nabla$ & $\nabla$ & $\nabla$ & - & - & - & - & - & - & - & • & • & $\Delta$ & $\Delta$ & $\Delta$ & $\Delta$ & $\Delta$ & $\Delta$ & $\Delta$ & $\Delta$ & $\Delta$ & $\Delta$ \\
\hline CZE & 538 & 95 & $\nabla$ & $\nabla$ & $\nabla$ & $\nabla$ & $\nabla$ & • & - & • & - & • & • & • & • & • & • & $\Delta$ & $\Delta$ & $\Delta$ & $\Delta$ & $\Delta$ & $\Delta$ & $\Delta$ & $\Delta$ \\
\hline ENG & 529 & 106 & $\nabla$ & $\nabla$ & $\nabla$ & $\nabla$ & $\nabla$ & $\nabla$ & - & - & - & - & - & - & • & - & • & $\boldsymbol{\Delta}$ & $\Delta$ & $\Delta$ & $\Delta$ & $\Delta$ & $\Delta$ & $\Delta$ & $\Delta$ \\
\hline DNK & 528 & 106 & $\nabla$ & $\nabla$ & $\nabla$ & $\nabla$ & $\nabla$ & $\nabla$ & - & - & - & - & - & • & - & - & - & $\Delta$ & $\Delta$ & $\Delta$ & $\Delta$ & $\Delta$ & $\Delta$ & $\Delta$ & $\Delta$ \\
\hline DEU & 526 & 98 & $\nabla$ & $\nabla$ & $\nabla$ & $\nabla$ & $\nabla$ & $\nabla$ & - & - & • & - & - & - & • & - & - & $\Delta$ & $\Delta$ & $\Delta$ & $\Delta$ & $\Delta$ & $\Delta$ & $\Delta$ & $\Delta$ \\
\hline CHE & 522 & 94 & $\nabla$ & $\nabla$ & $\nabla$ & $\nabla$ & $\nabla$ & $\nabla$ & • & - & • & • & - & • & - & • & • & • & • & $\Delta$ & $\Delta$ & $\Delta$ & $\Delta$ & $\Delta$ & $\Delta$ \\
\hline SVN & 513 & 94 & $\nabla$ & $\nabla$ & $\nabla$ & $\nabla$ & $\nabla$ & $\nabla$ & $\nabla$ & $\nabla$ & • & • & • & • & • & - & - & • & • & • & $\Delta$ & $\Delta$ & $\Delta$ & $\Delta$ & $\Delta$ \\
\hline HUN & 512 & 87 & $\nabla$ & $\nabla$ & $\nabla$ & $\nabla$ & $\nabla$ & $\nabla$ & $\nabla$ & $\nabla$ & • & • & • & • & • & • & - & • & • & • & $\Delta$ & $\Delta$ & $\Delta$ & $\Delta$ & $\Delta$ \\
\hline RUS & 494 & 87 & $\nabla$ & $\nabla$ & $\nabla$ & $\nabla$ & $\nabla$ & $\nabla$ & $\nabla$ & $\nabla$ & $\nabla$ & $\nabla$ & $\nabla$ & $\nabla$ & • & • & • & - & • & - & • & • & • & • & $\Delta$ \\
\hline BGR & 493 & 109 & $\nabla$ & $\nabla$ & $\nabla$ & $\nabla$ & $\nabla$ & $\nabla$ & $\nabla$ & $\nabla$ & $\nabla$ & $\nabla$ & $\nabla$ & $\nabla$ & • & • & • & • & - & • & • & • & • & • & $\Delta$ \\
\hline BFR & 486 & 107 & $\nabla$ & $\nabla$ & $\nabla$ & $\nabla$ & $\nabla$ & $\nabla$ & $\nabla$ & $\nabla$ & $\nabla$ & $\nabla$ & $\nabla$ & $\nabla$ & $\nabla$ & • & • & • & • & - & • & • & • & • & $\Delta$ \\
\hline PRT & 482 & 98 & $\nabla$ & $\nabla$ & $\nabla$ & $\nabla$ & $\nabla$ & $\nabla$ & $\nabla$ & $\nabla$ & $\nabla$ & $\nabla$ & $\nabla$ & $\nabla$ & $\nabla$ & $\nabla$ & $\nabla$ & • & • & - & - & • & • & • & $\Delta$ \\
\hline EST & 469 & 86 & $\nabla$ & $\nabla$ & $\nabla$ & $\nabla$ & $\nabla$ & $\nabla$ & $\nabla$ & $\nabla$ & $\nabla$ & $\nabla$ & $\nabla$ & $\nabla$ & $\nabla$ & $\nabla$ & $\nabla$ & • & • & • & • & - & • & • & • \\
\hline ROM & 468 & 98 & $\nabla$ & $\nabla$ & $\nabla$ & $\nabla$ & $\nabla$ & $\nabla$ & $\nabla$ & $\nabla$ & $\nabla$ & $\nabla$ & $\nabla$ & $\nabla$ & $\nabla$ & $\nabla$ & $\nabla$ & • & • & • & • & • & - & • & • \\
\hline LTU & 465 & 92 & $\nabla$ & $\nabla$ & $\nabla$ & $\nabla$ & $\nabla$ & $\nabla$ & $\nabla$ & $\nabla$ & $\nabla$ & $\nabla$ & $\nabla$ & $\nabla$ & $\nabla$ & $\nabla$ & $\nabla$ & • & • & • & • & • & • & - & - \\
\hline LVA & 446 & 87 & $\nabla$ & $\nabla$ & $\nabla$ & $\nabla$ & $\nabla$ & $\nabla$ & $\nabla$ & $\nabla$ & $\nabla$ & $\nabla$ & $\nabla$ & $\nabla$ & $\nabla$ & $\nabla$ & $\nabla$ & $\nabla$ & $\nabla$ & $\nabla$ & $\nabla$ & • & • & • & - \\
\hline
\end{tabular}


country groupings. For instance, although Norway-a long-standing democracy with a civic notion of citizenship, high economic development, a long history of civic education, and an emphasis on the open classroom methodwas found near the top of the CCCI rankings supporting the positive influence of these factors on civic competence, other similar countries with long histories of democracy, stability, civic understanding of citizenship, and economic development (e.g., Sweden, Denmark, Finland, and England) were found in the middle part of the CCCI rankings. It was perhaps even more surprising that the French-speaking part of Belgium scored near the bottom in the CCCI rankings, given that it is part of a long-established democracy, has a civic conceptualization of citizenship, and has had a greater degree of economic prosperity than the former communist and Southern European states. One possible explanation of francophone Belgium's lower ranking on the CCCI is that citizenship education was not a specific subject at the time of the study, though relevant topics were taught in a range of curricular areas.

Furthermore, two countries with interrupted experiences of democracy(Greek-speaking) Cyprus and Greece-were observed to have the highest rankings in the overall CCCI and in the domains of citizenship values, participatory attitudes, and cognition about democratic institutions, supporting the alternative hypothesis that greater instability facilitates civic competence. In addition, civic education is taught as a discrete subject in both of these countries. However, the civic education classes in Greece and (Greek-speaking) Cyprus are considered limited in terms of their use of interactive teaching methods, despite the 1981 introduction of teacher training and teacher guides advocating more child-centered pedagogies in Greece (Makrinioti and Solomon 1999).

In the search for possible alternative explanations, we explored further into the civic culture and education systems of these two countries. It is worth noting, in this regard, that Greece and (Greek-speaking) Cyprus have a number of commonalities, such as a common Greek cultural heritage from the classical period, when democracy was first introduced in Greece, and recent transition back from dictatorship to democracy. Greece began its transition to democracy in 1974, and Cyprus became an independent country (from the United Kingdom) in 1960 but then experienced a military government between 1967-74 before also becoming a democracy. Cyprus is an island split between Greek Cypriot and Turkish Cypriot communities, and it was only the Greek Cypriots who participated in IEA CIVED. In 1999 both Greece and (Greek-speaking) Cyprus had civic education in the primary and secondary education curricula. Previously both countries put great emphasis on patriotic education, with Greek Cypriot students being focused on the national history of Greece and on Greek Cypriot national identity (Makrinioti and Solomon 1999; Papanastasiou and Koutselini-Ioannidou 1999).

Portugal and Italy, which are similar to Cyprus and Greece in terms of 
relatively recent transitions to democracy and which also had civic education in the curriculum, also performed well in the rankings for the overall CCCI, with citizenship values, participatory attitudes, and social justice (for Portugal only) and cognition (Italy only) coming in the top half of the results. Additionally, while some former communist countries (e.g., Poland, Slovakia, and Romania) were near the top of the overall CCCI rankings, two other former communist states (the Baltic states of Estonia and Latvia) were at the bottom of the CCCI rankings. The performance of Poland, Slovakia, and Romania was not expected, in that these countries cannot be significantly separated from the remaining former communist countries in terms of having had recent transitions to democracy, similar levels of wealth, an ethnic conceptualization of citizenship, and citizenship education as a subject in the curriculum. In this circumstance, we could attribute these results to the differing civic education programs. The lower performances for the Baltic states is more in line with sociopolitical theory, given their ethnic understandings of citizenship; long history of occupation, dictatorship, and communism; and only a recent creation of the nation-state. In addition, these countries have more traditional forms of teaching and only recently introduced programs called democratic citizenship education.

Germany, which is in the unusual case of being a highly economically developed country with an experience of communism, ethnic notions of citizenship, and citizenship education as a discrete subject, has low results for the overall civic competence indicator. This result suggests that wealth and civic education in the curriculum of the country are not the only factors driving the levels of youth civic competence.

\section{The Four Domains}

Concerning the four domains of the composite (Social Justice Values and Attitudes, Cognition about Democratic Institutions, Participatory Attitudes, and Citizenship Values), there were some country groupings in the results that deserve further exploration. In line with the initial proposition that increasing the years of stable democracy is facilitating civic competence and that conceptions of civic forms of citizenship would have positive effects on the values of tolerance and equity, Norway and England were high performers on the domain of Social Justice Values and Attitudes, while Sweden, Denmark, Finland, and Belgium are in the top half of the rankings. Both the influence of the late transition to democracy and the ethnic conceptualization of citizenship would lead us to expect the lower results for the Russian Federation, Hungary, Bulgaria, and Latvia, which was observed in this domain. The position of Germany with other former communist countries within this lower half of the ranking suggests that these results may be influenced more (and negatively) by an ethnocultural understanding of citizenship (prevalent within these countries) that has been associated in the past with racist attitudes 
(Kohn 2008). However, the high ranking in this domain of Poland, another former communist country, does not follow this pattern.

The above country groupings are less clearly defined/differentiated for the domain of Cognition about Democratic Institutions but still tend to support the theory that more years of democracy and civic understandings of citizenship have a positive influence on the country results. Thus, the top half of the table is dominated by countries with stable and civic democracies. However, and in addition, Southern European countries, which have experienced interrupted years of democracy, are also in the top half of rankings on this dimension. Nevertheless, and in comparison to its Southern European neighbors, Portugal does not perform well on this dimension. One reason for Portugal's lower performance could be that civic education had (in 1999) only recently been introduced as a discrete subject in the curriculum (Menezes et al. 1999).

In contrast to Western Europe, Eastern European countries with the most recent transition to democracy tend to be located in the bottom half of the table for Cognition about Democratic Institutions, with Romania and the Baltic states of Estonia, Lithuania, and Latvia again being ranked very low. The lower rankings for most of the Eastern European countries on the social justice and cognitive domains may be due to their previous experiences of communism, ethnocultural conceptions of citizenship, low economic development, and only recent introduction of democratic civic education.

Interestingly, not all former communist countries were ranked low on the domain of Cognition about Democratic Institutions. The exceptions to these results are for Slovakia and Poland, which are high-performing countries for this dimension. The Polish exception might be due to the fact that (a) in Poland the notion of civil society and communitarian notions of democracy developed outside the education system within the resistance movements and the Catholic church prior to the fall of communism (Buk-Berge 2006) and/or (b) Poland had a civic education curriculum that was orientated toward everyday life in a democracy, in particular, focusing on civil society and the community (Slomczynski and Shabad 1998).

In contrast, the results for the domain of Participatory Attitudes are more in line with the alternative hypothesis that political instability facilitates civic competence among youth. First, we observed that Southern and former communist European countries of (Greek-speaking) Cyprus, Portugal, Romania, Poland, and Slovakia were ranked relatively high. Second, the results indicated that most of the stable democracies (Denmark, Sweden, Finland, England, Belgium [Fr], and Switzerland) were found toward the bottom of the rankings. Nevertheless, the low rankings of former communist countries (Estonia and the Czech Republic) do not follow this pattern.

The domain of Citizenship Values suggests a similar pattern, with the former communist countries of Romania and Lithuania achieving high per- 
formances along with the less stable and interrupted democratic experiences of Cyprus, Greece, Portugal, and Italy. In addition, and in line with the alternative hypothesis, ${ }^{9}$ stable democracies of Europe generally perform less well, with Denmark, England, Belgium (Fr), and Finland at the bottom of the rankings for this domain (see table 3).

For the domains of Citizenship Values and Participatory Attitudes, there is more evidence to support the alternative hypothesis that countries in Northern and Western Europe, which have longer and more stable democracies (mostly originating from the nineteenth century or earlier), facilitate apathy rather than an orientation toward participation. Thus, the more unstable countries, which have experienced recent transition to democracies, seem to be facilitating young people to place a greater value on participation in democratic systems (see also Torney-Purta et al. 2008).

\section{Conclusions}

This article represents a first attempt to measure-using CIVED datacivic competence as a holistic concept combining cognitive (knowledge and skills) and affective (attitudes and values) dimensions together. The results of comparing European countries on this composite measure as well as the four domains of civic competence (Citizenship Values, Social Justice Values and Attitudes, Participatory Attitudes, and Cognitions about Democratic Institutions) offer insights, but they must also be considered exploratory in their nature and tentative in their interpretation. There are some caveats to the results. For instance, the CIVED data do not include measures of all the aspects of civic competence as conceptualized above. Additionally, the analyses were conducted with data from 14-year-old pupils only and may not represent the populations more generally in the countries studied.

The CCCI rankings presented in this article demonstrate a complexity of country results that challenge the traditional theories regarding the influence of sociopolitical histories, economic development, and education on civic competence. The results do not suggest a single factor driving the levels of civic competence but suggest instead a number of sometimes even contradictory influences that include a historical political dimension, national conceptualizations of citizenship, economic development, and civic education. For instance, the high performances of less wealthy countries like Greece and Poland, and the low performances of a wealthy country like Germany, suggest that wealth is not the single most important factor influencing youth civic competences.

The results suggest that countries offering civic education as a discrete subject have higher rankings than would be expected based on other factors. For example, Greece, Cyprus, and Poland, which would be expected to have

${ }^{9}$ However, the finding that Estonia was at the bottom of the rankings is in line with expectations. 
low scores from most of the influences discussed, performed exceptionally well, in line with the fact of their having civic education as a discrete curricular subject. These results suggest support for Niemji and Junn's (1998) research that citizenship education can promote the learning of civic competence. These results provide encouragement for proponents of civic education, especially the Polish case, for which evaluation studies point to the innovative and effective teaching methods being employed in civic education (Slomczynski and Shabad 1998).

The findings in the domains of Citizenship Values and Participatory Attitudes give some support for the alternative hypothesis that instability and transition toward democracy facilitates an orientation toward democratic participation. This raises the question for those working in the field of civic education regarding how to develop enthusiasm for democratic participation within the stable democracies. In addition, the rankings for these domains also do not reflect systematically the patterns of adult civic participation in Europe (Hoskins et al. 2006; van Deth et al. 2007; Hoskins and Mascherini 2009). This raises questions as to whether there will be changes in such patterns of adult civic participation as this generation of young Europeans (i.e., those who were 14 years old in 1999) moves into adulthood, with future levels of adult participation lower within the long-standing European democracies and higher in the less stable Southern and Eastern European societies.

The results for the Social Justice and Cognitive domains suggest more support for the first hypothesis, that greater democratic stability and civic notions of citizenship would enhance civic competence. The lower results for Eastern European countries in the cognitive domain call for further work on the civic education programs in these countries, perhaps adapting the apparently successful efforts in Poland. The low results for some former communist countries on the domain of social justice could be influenced by ethnic conceptualizations of citizenship, which tended in the past to yield less tolerant attitudes toward those viewed to be nondescendants. This result raises policy-related questions concerning the possibility of tackling the high levels of intolerance toward minorities and lack of belief in gender equality within many countries in this region.

In sum, it is the complexity of the various influences on the development of civic competences across countries that we have found rather than support for a single or unidirectional theoretical explanation for the levels of youth civic competence across Europe. The results presented in this article suggest that the age of a democracy plays both a positive and a negative role on different aspects of civic competence and that citizenship education can help to produce better than expected results for some countries. 


\section{References}

Abs, Hermann Joseph, and Rudd Veldhuis. 2006. "Indicators on Active Citizenship: The Social, Cultural and Economic Domain." Paper presented at the European Commission (CRELL) Conference on Working toward Indicators on Active Citizenship, Ispra, Italy.

Almond, Gabriel, and Sydney Verba. 1963. Civic Culture. Princeton, NJ: Princeton University Press.

Audigier, François. 2000. Basic Concepts and Core Competencies for Education for Democratic Citizenship. Strasbourg: Council of Europe Publishing.

Brubaker, Roger. 1996. Citizenship and Nationhood in France and Germany. Cambridge, MA: Harvard University Press.

$\rightarrow$ Buk-Berge, Elisabeth. 2006. "Missed Opportunities: The IEA's Study of Civic Education and Civic Education in Post-Communist Countries." Comparative Education 42 (4): 533-48.

Education Council. 2006. "Recommendation of the European Parliament and the Council of 18, December 2006, on Key Competencies for Lifelong Learning." Official Journal of the European Union, December 30, L394/10-18.

Education Council. 2007. "Council Conclusions on a Coherent Framework of Indicators and Benchmarks for Monitoring Progress towards the Lisbon Objectives in Education and Training." Legal agreement by the member states of the Council of the European Union, Brussels.

European Commission. 2008. "Commission Staff Working Paper: Progress towards the Common Objectives in Education and Training Indicators and Benchmarks." European Commission, Brussels.

Eurydice. 2005. Citizenship Education at School in Europe. Brussels: Eurydice.

$\rightarrow$ Finkel, Steven, and Howard Ernst. 2005. "Civic Education in Post-apartheid South Africa: Alternative Paths to the Development of Political Knowledge and Democratic Values." Political Psychology 26 (3): 333-64.

Follesdal, Andreas, and Simon Hix. 2005. "Why There Is a Democratic Deficit in the EU." European Governance Papers (EUROGOV) no. C-05-02, Brussels.

Hahn, Carol. 1998. Becoming Political: Comparative Perspectives on Citizenship Education. New York: SUNY Press.

Hoskins, Bryony. 2006. "Draft Framework on Indicators for Active Citizenship." Paper presented at the European Commission (CRELL) Conference on Working towards Indicators on Active Citizenship, Ispra, Italy

Hoskins, Bryony, and Ruth Deakin Crick. 2008. Competencies for Learning to Learn and Civic Competence: Different Currencies or Two Sides of the Same Coin? CRELL research paper, EUR 23360. Luxembourg: Official Publications of the European Communities.

Hoskins, Bryony, Beatrice D'Hombres, and JoAnn Campbell. 2008. Does Formal Education Have an Impact on Active Citizenship Behaviour? CRELL research paper, EUR 23399. Luxembourg: Official Publications of the European Communities.

Hoskins, Bryony, Joachim Jesinghaus, Massimiliano Mascherini, Guisepe Munda, Michela Nardo, Michaela Saisana, Daniel Van Nijlen, Daniela Vidoni, and Ernesto Villalba. 2006. Measuring Active Citizenship in Europe. CRELL Research 
Paper, EUR 22530 EN. Luxembourg: Official Publications of the European Communities.

$\rightarrow$ Hoskins, Bryony, and Massimiliano Mascherini. 2009. "Measuring Active Citizenship through the Development of a Composite Indicator." Journal of Social Indicator Research 90 (3): 459-88. http://dx.doi.org/10.1007/s11205-008-9271-2.

Hoskins, Bryony, Ernesto Villalba, Daniel Van Nijlen, and Carolyn Barber. 2008. Measuring Civic Competence in Europe: A Composite Indicator based on IEA Civic Education Study 1999 for 14-Year-Olds in School. CRELL research paper, EUR 23210. Luxembourg: Official Publications of the European Communities.

Husfeldt, Vera, Carolyn Barber, and Judith Torney-Purta. 2005. "Students' Social Attitudes and Expected Political Participation: New Scales in the Enhanced Database of the IEA Civic Education Study." Civic Education Data and Researcher Services, College Park, MD.

Hyland, Terry. 1994. Competence, Education and NVQs: Dissenting Perspectives. London: Cassell.

IEA (International Association for the Evaluation of Educational Achievement). 2007. "International Civic and Citizenship Education Study: Assessment Framework." International Association for the Evaluation of Educational Achievement, Amsterdam.

Inglehart, Ronald F., and Christian Welzel. 2005. Modernization, Cultural Change, and Democracy: The Human Development Sequence. New York: Cambridge University Press.

$\rightarrow$ Kennedy, Kerry John, Carole Hahn, and Wing-On Lee. 2007. "Constructing Citizenship: Comparing the Views of Students in Australia, Hong Kong, and the United States." Comparative Education Review 52 (1) 53-91.

Kohn, Hans. 2008. The Idea of Nationalism: A Study in Its Origins and Background. London: Transaction Publishers.

Makrinioti, Dimitra, and Joseph Solomon. 1999. "The Discourse of Citizenship Education in Greece: National Identity and Social Diversity." In Civic Education across Countries: Twenty-four National Case Studies from the IEA Civic Education Project, ed. Judith Torney-Purta, John Schwille, and Jo-Ann Amadeo. Amsterdam: IEA.

Maroy, Christian. 2004. "Final Report: Regulation and Inequalities in European Education Systems." Université Catholique de Louvain, Louvain.

Mascherini, Massimiliano, Andrea Saltelli, and Daniela Vidoni. 2007. The Characteristics of Social Participation in Europe: Evidence from ESS2002. EUR 23088 EN. Luxembourg: Official Publications of the European Communities.

Masters, G. N., and B. D. Wright. 1997. "The Partial Credit Model.” In Handbook of Modern Item Response Theory, ed. W. J. van der Linden and R. K. Hambleton. Berlin: Springer.

Menezes, Isabel, Elisabete Xavier, Carla Cibele, Gertrudes Amaro, and Bartolo P. Campos. 1999. "Civic Education Issues and the Intended Curricula in Basic Education in Portugal." In Civic Education across Countries: Twenty-four National Case Studies from the IEA Civic Education Project, ed. Judith Torney-Purta, John Schwille, and Jo-Ann Amadeo. Amsterdam: IEA.

$\rightarrow$ Mok, K. H. 2005. "Riding over Socialism and Global Capitalism: Changing Education Governance and Social Policy Paradigms in Post-Mao China." Comparative Education 41 (2): 217-42. 
Nardo, Michela, Michaela Saisana, Andrea Saltelli, Stefano Tarantola, Anders Hoffman, and Enrico Giovannini. 2005. "Handbook on Constructing Composite Indicators: Methodology and User Guide.” OECD Statistics working paper. Organization for Economic Cooperation and Development, Paris.

Niemji, Richard, and Jane Junn. 1998. Civic Education: What Makes Students Learn. New Haven, CT: Yale University Press.

Papanastasiou, Constantinos, and Mary Koutselini-Ioannidou. 1999. "National Identity in the Civic Education of Cyprus." In Civic Education across Countries: Twentyfour National Case Studies from the IEA Civic Education Project, ed. Judith TorneyPurta, John Schwille, and Jo-Ann Amadeo. Amsterdam: IEA.

Putnam, Robert. 1993. Making Democracy Work: Civic Traditions in Modern Italy. Princeton, NJ: Princeton University Press.

Rychen, D. S., and L. H. Salganik, eds. 2003. Key Competencies for a Successful Life and a Well-Functioning Society. Göttingen: Hogrefe \& Huber.

$\rightarrow$ Sahlberg, Pasi. 2006. "Education Reform for Raising Economic Competitiveness." Educational Change 7 (4): 259-87.

Schulz, Wolfram, and Heiko Sibberns. 2004. IEA Civic Education Study Technical Report. Amsterdam: IEA.

$\rightarrow$ Shulman, Stephen. 2002. "Challenging the Civic/Ethnic and West/East Dichotomies in the Study of Nationalism." Comparative Political Studies 35 (5): 554-85.

Sibberns, Heiko, and Pierre Foy. 2004. "The CIVED Sampling Design.” In IEA Civic Education Study Technical Report, ed. H. Sibberns and P. Foy. Amsterdam: IEA.

$\rightarrow$ Slomczynski, Kazimierz M., and Goldie Shaba. 1998. "Can Support for Democracy and the Market Be Learned in School? A Natural Experiment in Post-Communist Poland." Political Psychology 19 (4): 749-79.

Soule, Susanne. 2003. "Beyond Communism and War: The Effect of Civic Education on the Democratic Attitudes and Behavior of Bosnian and Herzegovinian Youth." Working paper. Center for Civic Education, Calabasas, CA. http://www.civiced .org.

$\rightarrow$ Torney-Purta, Judith. 2002. "Patterns in the Civic Knowledge, Engagement, and Attitudes of European Adolescents: The IEA Civic Education Study." European Journal of Education 37 (2): 129-39.

$\rightarrow$ Torney-Purta, Judith., Carolyn Barber, and W. K. Richardson. 2004. "Trust in Government Related Institutions and Political Engagement among Adolescents in Six Countries." Acta Politica 39:380-406.

Torney-Purta, Judith, Rainer Lehmann, Hans Oswald, and Wolfram Schulz. 2001. Citizenship and Education in Twenty-eight Countries: Civic Knowledge and Engagement at Age 14. Amsterdam: IEA.

Torney-Purta, Judith, and Susan Vermeer Lopez. 2006. "Developing Civic Competencies from Kindergarten through Grade 12: A Background Paper for Policymakers and Educators." Education Commission of the States, Denver. http:// www.eric.ed.gov.proxy.lib.wayne.edu/PDFS/ED493710.pdf.

Torney-Purta, Judith, John Schwille, and Jo-Ann Amadeo. 1999. Civic Education across Countries: Twenty-four National Case Studies from the IEA Civic Educaton Project. Amsterdam: IEA.

$\rightarrow$ Torney-Purta, J., Britt Wilkenfeld, and Carolyn Barber. 2008. "How Adolescents in 
27 Countries Understand, Support and Practice Human Rights.” Journal of Social Issues 64:857-80.

Van Deth, Jan, Jose Ramon Montero, and Anders Westholm. 2007. Citizenship and Involvement in European Democracies: A Comparative Analysis. London: Routledge.

Veldhuis, Rudd. 1997. "Education for Democratic Citizenship: Dimensions of Citizenship, Core Competences, Variables and International Activities.” Report. Council of Europe, Strasbourg.

Watson, Keith. 2001. Doing Comparative Education Research: Issues and Problems. Oxford: Symposium Books.

$\rightarrow$ Weil, Frederick. 1985. "The Variable Effects of Education on Liberal Attitudes: A Comparative-Historical Analysis of Anti-Semitism Using Public Opinion Survey Data." American Sociological Review 50 (4): 458-74. 